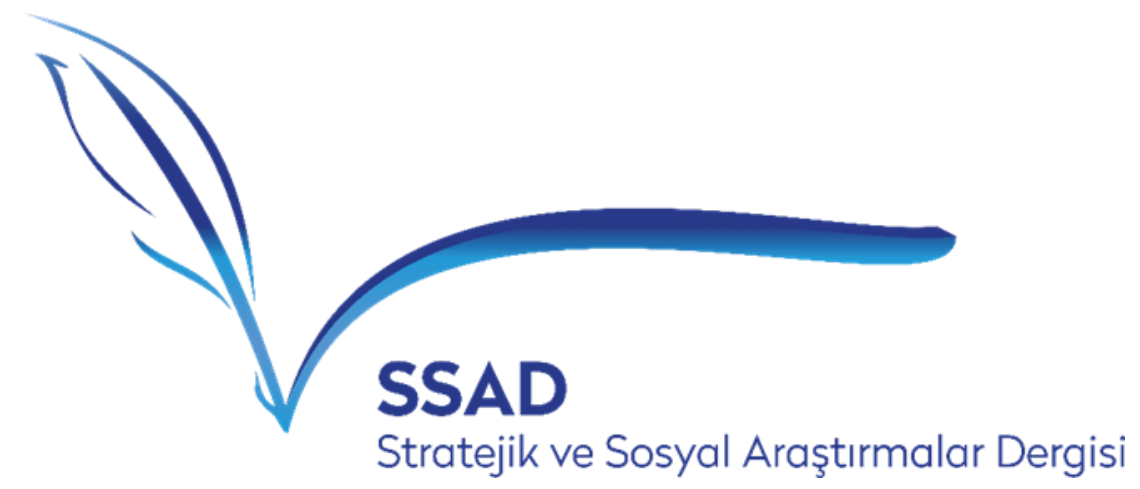

ISSN : 2587-2621

Volume 4 Issue 2, July 2020

ORCID ID: 0000-0002-5345-1935

Makale Gönderim Tarihi: 23.06.2020

Makale Kabul Tarihi: 07.07.2020

DOI: 10.30692/sisad.756811

\title{
TÜRK SANATINDA EJDER VE SU BİRLIIKTELİĞí
}

\section{The Togetherness of Dragon and Water in Turkish Art}

\section{J. Özlem OKTAY ÇEREZCI}

\author{
Dr. $\ddot{O} \breve{g r}$. Üyesi
}

Mimar Sinan Güzel Sanatlar Üniversitesi, Fen Edebiyat Fakültesi, Sanat Tarihi Bölümü

jale.ozlem.oktay@msgsu.edu.tr

\begin{abstract}
Özet: Türk kültüründe, evren başta olmak üzere pek çok sembolik anlamı bulunan ejderin yer-gök-su unsurları kapsamında değerli bir yeri vardır. Bazen iyilik bazen de kötülüğün sembolü olmuş bu gerçeküstü hayvan, zaman zaman da söz konusu iki zıt kavramı tamamlayan bir motif olarak Türk sanatında karşımıza çıkar. Çalışmamızı oluşturan Türk sanatında ejder ile su birlikteliği ise oldukça geniş bir yelpazede gerek erken devir gerekse Türk İslam sanatlarında izlenebilmektedir. Bununla birlikte ejderle su tasvirlerinin bulunduğu eserler detaylı olarak şimdiye kadar çalışılmamıştır. Ejder ile su birlikteliğini birkaç başlık altında toplamak mümkündür: Deniz, göl ya da nehirdeki ejder tasvirleri; havuzdaki ejder tasvirleri; çörten; su kemeri; köprü; çeşme; sürahi/ibrik ile maşrapalardaki ve şifa taslarındaki ejder tasvirleri. Tüm bu başlıklarda ejder tasvirlerinin ve sembolizminin çağlar boyu Türk sanatında, değişmeden ya da çok az farklılıklar göstererek gelmesi ilk dikkati çeken özelliktir. Söz konusu çalışmamızda yukarıda değinilen başlıklar altında, örneklerle ve sembolizme değinilerek Türk sanatında ejder ve su birlikteliği tanıtılmaya çalışılacaktır.
\end{abstract}

Anahtar Kelimeler: Ejder, su, Erken devir Türk Sanat1, Türk İslam Sanatı, sembolizm. 


\begin{abstract}
The dragon motif has an important place in the case of earth-sky-water concept in Turkish culture. And "Cosmos" is the most identification point for this fantastic animal. The dragon was sometimes symbolised good side and sometimes the bad side and also sometimes it combined these two opposite sides. The togetherness representations of dragon and water, which forms our research, has a very huge place not only in pre Islamic Turkish but in Turkish Islamic period art. However, this togetherness has not been studied before in details. We can categorise these representations under some topics such as: the dragons in the lake, river or sea; the dragons in the pool; the representations of dragons at the waterspout, bridge, aquaduct, fountain; ewer/jug and cup and healing bowls. The first point that take attention about these topics is, both the representations and the symbolic meanings of dragon's motifs can be traced for centuries without any changes or with small differences. In this research we will try to represent these dragon and water togetherness representations with the examples and symbolism at the Turkish art.
\end{abstract}

Keywords: Dragon, water, Early Period Turkish Art, Turkish Islamic Art, symbolism.

Sanat tarihi çerçevesi içinde ele alınan nesnelerin, eserlerin çoğu zaman işlevsel özelliklerinin yanı sıra sembolik yönleri de bulunmaktadır. Bu nedenle Türk sanatında ejder ve su birlikteliğinden bahsetmeden önce ejderin su ile ilişkili sembolik anlamına kısaca değinmekte fayda vardır.

\title{
EJDERIN SU ILE ILIŞKILİ SEMBOLIKK ANLAMI
}

Bilindiği üzere su, sadece insanlar için değil tüm canlılar için yaşam kaynağıdır. Yaşam için bu kadar önemli olan bir unsur ile ejderin zaman zaman birlikte tasvir edilmesi gerek sanatsal gerekse sembolik anlamda bahsettiğimiz birlikteliğin değerini vurgular. Türklerde ejder tasvirine ve bununla ilgili sembolizme çok erken tarihlerden itibaren rastlanılmaktadır. Bazen iyilik bazen de kötülügün sembolü bu gerçeküstü hayvan, zaman zaman da söz konusu iki zit kavramı tamamlayan bir unsur olarak Türk sanatında karşımıza çıkar. Ayrıca ejder, özellikle erken dönemlerden itibaren bereket, refah, güç, kuvvet simgesidir ve "iyi” kavrama işaret etmektedir (Çoruhlu, 2015: 172).

Evren başta olmak üzere pek çok sembolik anlamı bulunan ejderin yer-gök-su kavramı kapsamında değerli bir yeri vardır; ejder Çin kültüründe olduğu gibi Türk kültüründe de suyun (sıvının) kudretidir. Chou Devri ve öncesine ait kayıtlardan edinilen bilgilere göre ak ejder ya da yar1-insan yarı-balık şeklinde ejder ongunlu "mabud"lar ve "mabude"ler bulunmaktaydı. Bunların merkezi ise Yaş11-Ögüz olarak isimlendirilen yer idi. Buradaki efsanelerin benzerlerine Hotan'da, yeşim taşı çıkan bir dere çevresinde rastlanmaktadır. Bu husus önemlidir çünkü aşağıda değineceğimiz üzere ejder kulplu bazı maşrapaların yeşim taşından üretilmesi belki de bu efsanelerden kaynaklanmaktadır. Göktürklerle ilgili bir efsanede bir Göktürk avcısı, ejder unsurları taşıyan bir su "mabude"si ile evlenmişti (Esin, 1979: 37). Ejder ile su ilişkisinin ne derece güçlü olduğunun başka bir kanıtı da Göktürklerin yaz dönümünde su ejderine kurban sunmalarıdır. Ejder, bahsettiğimiz anlamlarına ek olarak yeniden doğuşu, hayatı, ölümsüzlüğü ve sonsuzluğu ifade eder. Çünkü yukarıda da değindiğimiz üzere, insanların varlığını devam ettirmesindeki en önemli unsurlardan birinin içinde, suda yaşamaktadır. Özellikle gölde yaşayan ejder ölümsüzlük veya ölümsüzlük getiren hayat suyu ile ilişkilendirilir (Çoruhlu, 2011: 128).

Ejder ayrıca, göllerden ya da nehirlerden geçerken nemi, yağmuru dünyaya dağıtır ve böylece yeryüzündeki bereketi kontrol etmiş olur. Derin sularda yaşayan yer ejderi bahar döneminde sudan çıkar; sakala, pullara, kanatlara ve boynuza sahip olarak gökyüzüne uçar ve bulutların arasına girer. Böylelikle yağmur yağmasını sağlar, başka bir deyişle suyun yani yine hayatın devamının önemli bir simgesi olarak yeryüzüne bolluk ve bereket getirir (Çoruhlu, 2010: 132). Bu özelliği, aşağıda ele alacağımız gerek erken devir Türk gerekse Türk İslam tasvir sanatındaki tasviri ile gözler önüne serilmektedir. İlaveten, Esin'den edinilen bilgilere göre "Kök-luu" (Kutadgu Bilig'de evren adıyla geçmektedir) yani gök ejderi, gök gürültüsü ve yağmur simgesi olarak, Türk Budist metinlerinde hükümdar niteliği taşımaktaydı (Esin, 2001: 83-85, 116). Ayrıca bulutların arasına girmesinden dolayı ejder, zaman zaman bulut motifinin kendisi ile de 
ilişkilendirilmiştir (Boydak, 2017: 283-288). 12 Hayvanlı Türk Takvimi'nde de yerini alan bu hayvanın yılında çok yağmur yağar, bolluk ve bereket olacağına inanılır (Öney, 1969: 192). Bunlara ek olarak ejder, mevsim dönüşümlerine ve dolayısıyla astrolojik birtakım sembollere işaret eder.

Ejderin bulutlar arasına karışıp yağmur yağdıran bir sembol oluşu ve astroloji ile bağlantısı Türk İslam inançlarında ve sanatında devam etmiştir (And, 1998: 326); ejder bazen Tenniyn Yıldızı ile ilişkilendirilmiştir. Acaib-ül-Mahlukat'tan iki örnekte ise bulutların arasına dolanmış olarak gösterilen ejderler Uygur Dönemi örneğini anımsatırcasına göğe yükselmişler ve sanki yağmur yağdıracakmış izlenimi vermektedirler (Görsel 1c-d ).

Ejderler mimari unsurlarda da karşımıza çıkmakta ve yukarıda değinilen sembolik anlamları devam ettirmektedirler. Özellikle çörtenlerde bereketi getiren suyun bekçisi olarak görülürler (Doğanay, 2017: 131). Ejder figürlü çörtenlerden gelen suyun şifalı olduğuna inanılır. Lale Devri şairi Nedim'in "Görelim âb-ı hayat aktı̆̆ın ejder-hadan” mısra1 da Hayat Suyu'nun ejderin ağzından aktığı inancı ile paralellik göstermektedir. Bu açıdan baktığımızda ejder tasvirlerinin çörtenler dışında çeşme lülelerinde, maşrapalarda ve şifa taslarında yer alması anlam kazanmaktadır. Görüldüğü üzere Türk kültüründe ejderin su ile ilgili sembolizmi nerdeyse her zaman iyiliğe, berekete, şifaya işaret eder. Ayrıca nadir olsa da suluklarda görülen, ortasında inci taşıyan ve spiral gövdeli ejder çifti, çarkıfeleği çeviren ejder çiftlerini anımsatır ve bu anlamda Kutadgu Bilig'de de geçen ejderlerin "evren" olarak anılmalarını hatırlatır (Atalay, 1992: 109).

Esin'in de evren diye nitelendirdiği ve Türklerde "luu" ya da "nek" adıyla anılan ejderin (Esin, 1970: 161-162) suyla ilişsisine bağlı olarak balık, ejderin kozmik simgelerinden biridir (Esin, 1979: 89). Ayrıca, ağaç motifi ve su bitkisi olan nilüfer yani lotus da zaman zaman ejder ile birlikte tasvir edilmiştir (Esin, 1970: 163) (Görsel 17 a). Söz konusu durumdan anlaşılacağ 1 üzere ejderler burada dolaylı olarak su ile ilişkilidir. Bununla ilgili başka bir örnek de 13. yüzyıl sonuna ait N. Sivasî'nin Malik Abû Ahnaf'ın tasviridir (Görsel 17b); Malik Abû Ahnaf, aslan bineği üzerinde bir elinde kap diğer elinde suyun timsali olan ejderi tutmaktadır.

Araştırma konumuzu oluşturan Türk sanatında ejder ile su birlikteliğine baktığımızda bunları üç ana grup altında toplamak mümkündür.

\section{DENIZ, GÖL VE NEHIRDEKİ EJDER TASVİRLERİ}

Ejderlerin göl, nehir vb. içindeki tasvirleriyle ilgili erken döneme işaret eden bir sahne Asya Hunları Dönemi'ne aittir. Noin Ula Kurgan 20'den ele geçen (Polosmak vd, 2011: res. 6) iki adet at koşum takımına ait altın yaldızlı kanatlı ejder örneği (Görsel 1 a) bir yandan Uygur Dönemi'nden freskolarda göreceğimiz bahar getiren ejderleri anımsatır diğer yandan Türklerdeki ejder kültünün köklerinin geçmişi hakkında bize fikir verir.

Su içindeki ejder tasvirlerinin belki de en bilindik örneği Bezeklik 19. Tapınak'taki Uygur duvar resminde (Görsel 1b) bahar getiren ejder yani gök ejderidir (Le Coq, 1924: 49). Bir gölden çıkan bu ejder, çıkışı sırasında gök unsurunun özelliklerini barındırmaya başlar; başı üzerinde tepe gibi bir yumru oluşur, kanatlar, pullar ve boynuzlara sahip olarak değişimini tamamlar (Çoruhlu, 2011: 128). Bu ejderin başka bir özelliği de, Türk İslam sanatında da göreceğimiz üzere, badem gözlerinin olmasıdır. Değişimini tamamladıktan sonra bulutlar arasında uçmaya başlar. Bahar getiren ejder, yukarıda da değinildiği üzere aslında suların derinliklerinde yaşamakta, ekinoksta yeraltından yukarıya doğru çıkarak yeryüzüne erişmekte ve bulutların arasına karışarak yağmur yani bereket getirmekteydi (Çoruhlu, 2019: 58).

7. yüzyıla ait bir sahnede ise ejder mucize gerçekleştiren bir unsur olarak tasvir edilmiştir. Bir kıyıdan karşı tarafa geçmeye çalışan Buddha'ya yardım için ejder, nehirden ya da denizden çıkar 
ve gövdesini spiral yapacak şekilde kıvırarak sandal formuna sokar; böylece Buddha'nın karşı kıyıya ulaşmasını sağlar (Görsel 2) (Hartel, 1982: 58).

Türk İslam sanatına baktığımızda da bu anlayışın yani sudan çıkan ejderin iyi tarafının ve mucize gerçekleştiren yönünün çok değişmediği görülür. Örneğin, Hz. Yûnus'un, Cebrâil'in yardımıyla balığın karnından çıkması sahnesinde (her ne kadar Hz. Yûnus bir balık tarafından yakalanmışsa da balık ona zarar vermez ve onu tekrar kavminin olduğu yere bırakır) (Görsel 3) (Pakyüz, 2015: 100) ejder, tartışmalı olarak, olumlu yöne işaret etmektedir. Bu sahnede ejderin Uygur örneğindekine benzer biçimde boynuzlu olması, kaplumbağa, balık gibi çoğunlukla olumlu tarafa işaret eden hayvanlarla birlikte resmedilmesi, ejderi "iyi" en azından zarar vermeyen yönde algılamamızı sağlar. Ejderin nehir, göl ya da denizden çıkıp "mucize" ve "iyilik" ile ilgili sahnelerde yer almasının konu edildiği başka bir eser de Hamdî’nin (15. yüzyıl) Yûsuf-u Züleyhâ isimli minyatürlü yazmasında (Chester Beatty Library'deki 16 . yüzyıl örneği) görülmektedir (Görsel 4). Hz. Yûsuf çok güzel bir insandır, bunu bilen herkes onu görmek istemektedir. Hz. Yûsuf bir gün yıkanmak için Nil Nehri'ne girer, bunu duyanlar nehir kenarına gelip onu seyretmeye başlar. "Hz. Yûsuf kendisini örtecek bir yardım isteyince nehirden bir ejderha çıkar, dimdik durup Hz. Yûsuf'a bakılmasinı engeller” (And, 1998: 409). Söz konusu sahne, mucizeiyilik-su-ejder iliş̧kisi bakımından değindiğimiz 7. yüzyıl örneğini çağrıştırması yönünden dikkat çekmektedir.

\section{HAVUZ, ÇÖRTEN, SU KEMERİ, KÖPRÜ, SULUK VE ÇEŞMELERDEKİ EJDER TASVIRLERI}

Ejderin, Türk kültüründe önemli bir yere sahip havuz ile ilgili sahnelerdeki tasviri de erken tarihlerden itibaren izlenebilmektedir. Bezeklik 9. Tapınak'taki Uygur duvar resminde, dünyanın merkezindeki denizi temsil eden havuz ile bu havuzdan çıkan ejder çifti görülmektedir (Esin, 1982: 5) (Görsel 5a). Bu bağlamda onların hayat suyunu kontrol eden yönü öne çıkmıştır; söz konusu çift, çintemaniyi havuzdan çıkartıp göğe doğru yükseltmektedir. Ejderlerin bu inciyi yuttukları vakit yağmur getirdiklerine inanılmaktadır (Çoruhlu, 2019: 68). Uygur Dönemi'nden diğer bir örnek Koço A Tapınağı'ndan gelmektedir (Görsel 5b). Freskonun, parçalı olmasından dolayı, fazla detay vermediği bu örnekte havuz içinde ejder açık ağzı ile gösterilmiştir. Havuzda yer alan lotuslar su unsuru ile bağlantılı olarak ejder-lotus birlikteliğini yinelemektedir.

Türk İslam sanatı için havuzların özellikle fıskiyeli havuzların önemi yüzyıllar boyu devam etmiştir. Bunlar arasından ejder başlıklı havuz fiskiyeleri gerek mimari anlamda gerekse minyatür sanatında karşımıza çıkmaktadır (Görsel 6.a-b). Fiskiyelerin gövde ve başlarını oluşturan ejderlerin açık ve bazen dişlere sahip açık ağızlarından su çıkmaktadır. Örneğin, bir Şecaatnâme'de yer alan “Osman Paşa, Sultan III. Murad'ın Huzurunda” (İ̈KK. T. 6043, y.7b) isimli sahnenin aşağı kısımda görülen havuzun köşelerindeki fıskiyeler, yılan ya da ejder başına sahiptir, bu havuzun ortasında yükselen dairevi formdaki fiskiye de benzer biçimdedir.

Türk İslam sanatında özellikle minyatürlerde tanık olduğumuz ejder başlı ya da gövdeli havuz fiskiyeleriyle ilgili bilgilere Evliya Çelebi'den de ulaşılmaktadır: "Macaristan'daki Peçuy şehrinde bulunan Ferhad Paşa Hamamı'nın havuzundaki suların on iki ejderin ağzından fişkırdırdı̆̆g ve bu fiskiyenin üç öküz başı ile üç kaplumbă̆a üzerine oturduğu" bildirilmiştir (Bozkurt, 1998: 100).

Havuz ile ilgili ejder-su ilişkisi tasviri sadece yukarıda değindiklerimizle sinırlı değildir; minyatürlerde zaman zaman gördügümüz havuzdan akan kıvrımlı su da görüntü olarak ejder gövdesini anımsatması bakımından ele alınabilir. Hünernâme I.cilt'te yer alan "Bağdad'dan getirilen bir arslanın Sultan I. Osman'ın çizmesini yalaması" (TSMK. H. 1523, y. 57b) sahnesinde havuzun suyu, açıklıtan zikzak seklinde inerek sahnenin alt kısmında sonlanır. Benzer sahneleri 
çoğaltmak mümkündür; Hünernâme I. cilt, "Orhan Gazi'nin Kaluyaven Bey'e kendi çektiği bir oku hediye etmesi" (TSMK. H. 1523, y.72a) sahnesinde de altıgen havuzda bir kaynaktan çıkan ve kıvrılarak aşağı inen su görülmektedir (Görsel 7) (Şimşek, 2019: 51, 58, 94).

Türk İslam sanatında binaları, insanları koruduklarına ve şifa getirdiklerine inanılan mimari ile ilişkili dikkat çeken diğer bir grubu da çörtenler oluşturmaktadır. Bununla birlikte ejder başlı çörtenlere nadir olarak rastlanmaktadır. Karaman Arapzade (Arapoğlu) Camii'nde batı cephede ahşap çatı altında ejder başlı çörtenler yer almaktadır (Görsel 8a); ağızları açık vaziyettedir ayrıca açık ağızlarından dişler, badem gözler ve sivri kulaklar seçilebilmektedir (Özüdoğru, 1989: 32). Bursa'da Abdullah Mustafa Türbesi'nde (15. yüzyıl) mevcut olan çörten de ejder başına sahiptir (Görsel 8b) (Doğanay, 2017: 132).

Ejder ile su birlikteliğinde, mimari anlamda çörtenlerden sonra Türk İslam sanatında eşine çok rastlanmayan birkaç örnek ise su kemerlerinde ve suluklarda karşımıza çıkar. I. Mahmud Su Kemeri kilit taşlarından bir tanesi ejder/yılan şeklindedir (Görsel 9a). Günümüze oldukça harap olmuş bir durumda gelen ejderin burun delikleri, açılmış ağız, sivri dişler ve öne doğru uzayan dil gibi detayları görülebilmektedir (Şahin ve Sönmezer, 2017: 114).

Edirne Meriç/Mecidiye Köprüsü (Osmanlı Dönemi, 19. yüzyıl) birinci boşaltma gözü üzerinde tasvir edilen ejder/yılan çifti konumuz açısından yine ender örneklerden birini teşkil etmektedir (Görsel 9b) (Akçıl Harmankaya, 2018: 153). Gövdeleri birbirine karşılıklı olarak yerleştirilmiş kabartma tekniği ile meydana getirilmiş bu gerçeküstü hayvanların başları birbirlerine zit yönde bakmaktadır. Detaylarda ise geleneksel olarak badem gözleri ve kulakları seçilebilmektedir.

Yine nadir bir örnek olarak, Acun'un bize aktardığı Eyüp'ten kareye yakın planlı taş suluk, ortasında dairevi formda iç içe geçen dört spiralden oluşan bir düzenlemeye sahiptir. En diş kısımda iki ejder vardır. Bunlardan bir tanesi daha net olarak seçilebilmektedir. Bu ejder badem gözlere sahiptir ve açık ağzından dişleri görülmektedir. Açık ağzından bir bakıma dişleri arasından suyun akabilmesi için bir dairevi formlu delik yer almaktadır. Benzeri durum diğer ejder için de söz konusudur. Ejderlerin kuyrukları ile Rumi motifi ile son bulur ki bu nokta suyun döngü yaptı̆̆ yerdir (Görsel 10) (Acun, 1997: 198-199). Ağızlarında ya da ortalarında inci tanesi tutan ejder çiftleri gök gürülttïsü ile yağmur ve dolayısıyla bereketi sembolize eder (Esin, 2001: 28). Ejder çiftlerinin ortasında yer alan inci tanesi aynı zamanda özellikle Uygularda çintemani ile ilişkilendirilmekte ve ejder çifti tarafından korunmaktadır (Çoruhlu, 2019: 67-68). Söz konusu örnekte bir detay daha dikkati çekmektedir. Kare içindeki daire şeması Türklerde evren ile ilişkilendirilen unsurlardan biridir; Türkler yeryüzünü dörtgen ve bunun içinde yer alan daireyi de gök olarak kabul etmekteydiler.

Türk sanatında ejder ve su birlikteliği kapsamında ikinci ana grup altındaki son alt grubu çeşme lüleri meydana getirmektedir. Örneğin, Anadolu'daki çeşmelerin bir kısmı ejder başlı lülelere sahiptir. Bunlardan bir tanesi Hatun Hanı'nın (1239) çeşmesidir (Görsel 11a ). Ejder başları boyun kısmından iç içe dairelerle meydana getirilmiş bir yaka ile çeşme aynasına bağlanmıştır (Önge, 1970: 183). Ejderlerin doğal olarak, su akması için ağızları açık tutulmuştur, hafif sivri kulakları ve badem gözleri ile çörtenlerdeki tasvirleri tekrarlarlar. Bu gruba ait daha stilize bir örnek ise Karakaya Kaplıca çeşmesine aittir (Görsel 11b); açık ağzında dişleri seçilebilmektedir, çene kısmında tüy izlenimi veren kıvrımlar yer alır. Ankara, Ayaş İlçesi'nde yer alan Karakaya Kaplıcası yanında bulunan çeşmenin (muht. 16. yüzyıl), ejder başlı bir lülesi olduğu bilinmektedir ancak ilerleyen yıllarda eskidiği için pirinçten yenisi yapılsa da birtakım detayları kaybolmuştur. Benzeri durum aynı yerdeki kaplıca havuzuna akan ejder başları için de geçerlidir. Çeşmelerde ejder ya da stilize ejderlere sonraki dönemlerde de rastlanılmaktadır; 18-19. yüzyılda Osmanlı Dönemi'nde bu tarz lüleler sevilerek kullanılmıştır (Görsel 11c). 


\section{MAŞRAPA, SÜRAHİ/BRIIK VE ŞIFA TASLARINDAKİ EJDER TASVİRLERİ}

Türk İslam sanatında ejder su ilişkisinin işlendiği en büyük grubu maşrapalar ve onları izleyen grubu ibrikler oluşturmaktadır. Maden başta olmak üzere porselen vd. malzemelerden yapılmış, Türk İslam Dönemi sürahi ve maşrapalarının bazılarında kulp ya da emzik kısımlarında ejder gövdelerini ve/veya başlarını görmek mümkündür.

Bunlar arasından özel bir grubu Türk İslam sanatında maşrapalar meydana getirir. Söz konusu kulplar genelde " $\mathrm{S}$ " şeklindedir; ejderlerin başları tasvir geleneklerine uygun olarak badem gözlere, kulaklara, boynuza, açık ağızlarından zaman zaman seçilebilen dişlere sahiptir ve kuyrukları çoğu kez içe doğru kıvrılarak delik işi tekniğinde bitkisel süsleme ile son bulur. Maşrapa kulplarındaki ejderler ağız kısımları ile maşrapanın ağzına, kuyruk kısımlarından ya da kuyruğa yakın bir yerden ise maşrapanın gövdesine sabitlenirler.

İlk başta maşrapa denildiğinde madenden yapılanlar akla gelse de yeşim taşından üretilmiş olanların sayısı da az değildir. Bununla ilgili nadir örneklerden ilki Lizbon Gulbenkian Koleksiyonu'na ait Caloueste Gulbekian Müzesi'nde bulunan beyaz yeşim taşından yapılmış bir maşrapadır (Görsel 12a). Söz konusu eserin muhtemelen Uluğ Bey zamanında Semerkant'ta üretildiği düşünülmektedir. Boyun kısmında Uluğ Bey'in adı geçmektedir (https://gulbekian.pt. Erişim Tarihi: 18.02.2020). Uluğ Bey'in adının geçtiği ve yeşim taşından yapılmış konu ile ilgili iki örnek daha bilinmektedir. Ejder kulplara sahip bu iki örnekten biri British Museum'da (Görsel 12b) diğeri ise Benares Bharat Kala Bhavan'da (Görsel 12c) yer almaktadır (Lentz ve Lowry, 1989: kat. 52, 124). Son iki örnek Uluğ Bey'in adını taşımakla birlikle üslup olarak Timurlu Dönemi kaplarından farklılık göstermektedir. Kulp kısımlarındaki ejder gövdeler "S" çizmez, "C" formunda kap gövdesine birleşir ancak böyle kulplara erken devir Orta ve İ́ç Asya bozkır kültüründe sıkça rastlanıldığını hatırlatmak gerekmektedir. Bu kaplar Çin'den getirtilmiş ya da Semerkant'ta Çinli bir usta tarafindan yapılmış izlenimi vermektedir (Pinder-Wilson, 1962, s. 4950). Söz konusu gruba, bize göre, San Francisco, Asian Art Museum'da the Avery Brundage Koleksiyon'da bulunan yine ejder kulplu oval bir kap (15. yüzyıl) da dahil edilmelidir (Görsel 12d) (Lentz ve Lowry, 1989: kat. no. 120).

Topkap1 Sarayı Müzesi'nde 1844 numara ile kayıtlı olan yeşim taşından maşrapa ise değineceğimiz madeni örneklere benzerliği ile dikkat çekmektedir (Görsel 12e) (Malekzadeh, 1976-1977: 263). Şah İsmail Safevi için dekore edilmiş bu eserin Tebriz'de üretildiği bilinmektedir (Lentz ve Lowry, 1989: 310). Eserin kulp kısmı ejder şeklinde tasarlanmıştır, ejderin gövdesi "S" formuna sahiptir; ağzı ile maşrapanın ağız kısmına ve kuyruğu ile gövde kısmına bitişiktir. Ejderin açık ağzından dişleri görülmektedir, badem gözlü ve kulaklıdır. Ejderin kuyruğu ise pek çok maşrapa örneğinde olduğu üzere içe doğru kıvrılarak rozet şeklini alır. Ense kısmında ise maşrapanın kapağının zincirinin geçirilmesi için tasarlanmış ufak bir ilmik yer almaktadır.

Madeni örneklerden birini Herat'ta üretilmiş ve Habib Allah İbn Ali Barzani tarafindan yapılmış olan, Londra Victoria ve Albert Müzesi'ndeki 1461-62 tarihli maşrapa oluşturur (Görsel 13a). Nuhad es-Said Koleksiyonu'ndan ejder kulplu maşrapa ise 1484 tarihlidir (Görsel 13b). Üzerindeki Farsça beyitte "bu kapta yaşam suyu var" (Allan, 1982: 110) şeklindeki ifade sembolik olarak ejder ve su birlikteliğindeki saflık ve ölümsüzlügü bir kez daha gözler önüne sermektedir. Paris'te ele geçen bu maşrapa üzerinde ayrıca Hüseyin İbn Mübarek Şah imzası yer almaktadır. TİEM'de yer alan 2963 Envanter Numaralı Timur Dönemi 1467 tarihli pirinç maşrapa (Görsel 13c); kulp kısmında "S" formlu, ağzı açık bir ejdere sahiptir; ejderin baş1 üç boyut oluşturacak şekilde ele alınmıştır. Kuyruğu daire yaparak içe kıvrılır ve iç kısımda rozet formunu alır. Ağız ve kuyruklarından maşrapanın gövdesine bitişik olan ejderin belirgin gözleri, kulakları ve pullu gövdesi ile erken dönem yani Uygur Dönemi örneklerini hatırlatır (Çevrimli, 2012: 200). Benzeri bir örnek 1512 tarihli Afganistan, Herat'ta ele geçmiştir (Görsel 13d), söz konusu eser 
David Koleksiyonu'nda yer almaktadır. Aynı koleksiyondan Osmanlı Dönemi'ne ait (yak. 1550) diğer bir maşrapa kulpunda yine bir ejdere rastlanmaktadır ancak buradaki ejderin kuyruğu içe doğru kıvrılmaz (Görsel 13e) (von Folsach, 2014: fot. 523, 531).

Bu maşrapalardaki ortak özelliklerden başta geleni yukarıda değinildiği üzere ejderlerin açık ağızları ile maşrapaların ağız, kuyrukları ile gövde kısımlarına bitişik olmalarıdır. Kuyrukları ajurlu olarak ve çoğunlukla rozet ya da bitkisel formda içe doğru dönüş yapar. Çoğu zaman kulakları ve ense kısmında bir çıkıntı/topuz seçilebilmektedir. Badem gözleri, kulak ve boynuzları ve açık ağızları ile Türk sanatındaki ejder ikonografisini tekrarlarlar.

Konumuz açısından ele aldığımız ibrikler de maşrapalardakilere benzer şekilde özellikle kulp kısımlarındaki ejderler ile karşımıza çıkmaktadırlar. Kaçkar Dönemi (1795-1925) ibriklerinden örneklerde bu tarz özellikleri görmek mümkündür. Örneğin Erzurum Arkeoloji Müzesi’nde söz konusu döneme ait bir grup ibriğin (Çınar, 2014: 163-183) çoğunun kulbunun ejder formunda olduğunu belirtebiliriz. Özellikle adı geçen müzedeki 31-98; 9-89 (Görsel 14a); 8-89 ve 7-89 envanter numaralı ibriklerin kulplarını oluşturan ejderlerin kuyruk uçlarının içeri doğru kıvrılması ve ajurlu olarak ele alınmaları yukarıda verdiğimiz maşrapa kulplarına benzerliği ile dikkat çekmektedir. Osmanlı Dönemi'nde ejder emzikli ya da kulplu ibriklerin kullanımlarının geç dönemlere kadar devam ettiği tespit edilmiştir. Meselâ, Adell Armatür Koleksiyonu'ndan (Gök, 2010: 149) 18. yüzyıla işaret eden gövde üzerinde damla formlu bir ibrik kulbunda ejder görülmektedir; ejderin kuyruğu topuz formunda sonlanır. Başında kulaklar, badem göz ve açık ağzı bulunmaktadır; ağzında bir inci tanesi tutuyor izlenimi vermektedir. Bu noktada ejderin inci tanesini yutması ile yağmur yağmasının bağlantısını bir kez daha hatırlarmakta fayda vardır; ayrıca gövde üzerindeki damla formu ile ejder-su birlikteliği pekiştirilmiş olur (Görsel 14b). 19. yüzyıla ait pirinç ibrik, hem emzik kısmında hem de kulbundaki ejder ile dikkati çeker (Görsel 14c). Kulptaki ejderin kuyruğu maşrapa kulplarındaki ejderlerin kuyrukları gibi daire şeklinde içe doğru kıvrılır. Emzik ve kulptaki ejderin başlarında kulaklar ve badem gözler seçilmektedir. Yanak kısımlarındaki yatay damla formu, açık ağızları ile birlikte düşünüldügünde laleyi anımsatmaktadır. Burada Osmanlı minyatürlerindeki bazı havuz fiskiyelerinin lale formunda olduklarına değinmekte fayda vardır.

İbrikler ile ilgili tasvirler ise çoğunlukla El Cezeri tarafindan ele alınmıştır. El-Cezeri'nin "ElCâmi' Beyne'l-İlm Ve'l-Amel En-Nâfi' Fi Es-Sinaâ’ti'ül-Hiyel” (El Cezerî, 2002: LIV-LV; LXXIV-LXXV) adlı eserinde yer alan "Abdest Almak İçin Düzenlenmiş Otomat" (Görsel 15a), "Abdest Almak İçin Su Döken Çocuk" (Görsel 15b), "Köleli Leğen" (Görsel 15c) sahnelerinde ibriğin emziğinin ejder başı ile sonlandığı görülmektedir. Bu da ejderin ağzından akan suyun şifalı, hayırlı olduğu görüşünü bir kez daha kanıtlar. Ejderlerin başında da kulak ve gözler seçilebilmektedir, su dökülmesi için ağızları açık verilmiştir. Yine aynı eserden su saatleri ile ilgili sahneler, ejderlerin yer alması bakımından dikkat çekicidir. "Kayık Su Saati” (Görsel 15d) isimli sahnede kayığın kirişlerinin ortasından geçen direğe bir ejder sarılmıştır. "Filli Su Saati"nde ise (Görsel 15e) hisarın filin başı yönündeki tarafinda bir balkon, balkonun sütunları arasında uzanan ve üzerine iki ejder sarılmış bir direk yer almaktadır. Buradaki ejderler de tıpkı gök ejderleri gibi kanatlı ve boynuzludur. Ağızları açık verilmiştir; son örnektekinde diller de bulunmaktadır (Korkutata, 2012: 47-56).

Ele alacağımız son grubu oluşturan şifa tasları ise daha çok tılsımla ilişkilidir ve bunlar üzerlerinde âyet ve duaların işlendiği kap ya da taslardır. Başka bir deyişle bu kaplardan su içen insan ya da hayvanların, hastalıklardan kurtulacaklarına inanılmaktadır (Gedük, 2017: 359). Bunlardan bazılarının iç kısımlarında yer alan tılsımlı hayvan tasvirleri arasında ejder de karşımıza çıkmaktadır. TSM Kutsal Emânetler Bölümü, 21/86 numaralı pirinç bir şifa tası (Görsel 16) konumuzla ilgili olarak ele alınabilir. Selçuklu Dönemi'ne ait söz konusu şifa tasında birbirine karşılıklı olarak bakan ve kuyrukları yaklaşık olarak ortada birbirine dolanmış ejder çifti görülmektedir. Ejder çiftinin evren düzenini, evren çarkını çeviren sağlayan ve sonsuzluğa işaret 
eden sembolizmi düşünüldüğünde, ejder ve su birlikteliği kapsamında şifa veren tastaki tasvirleri daha da anlamlı olmaktadır. Ayrıca birebir suyla ilişkili olmamakla birlikte ejder tasvirlerinin, "iyi", "güç", "kutsallık" gibi anlamlarını koruyarak, Türk İslam sanatında şamdan ve âlem kollarında da bulunduklarına kısaca değinmekte fayda vardır (Karamağaralı, 1976: 250 ).

\section{SONUÇ}

Ejder ile su birlikteliğinin tasviri görüldüğü üzere Türk sanatında gerek İslam öncesi gerekse İslam sanatında oldukça yaygın olarak kullanılmıştır. Söz konusu tasvirlerin kullanım alanlarını Deniz, Göl ve Nehirdeki Ejder Tasvirleri; Havuz, Çörten, Su Kemeri, Köprü ve Çeşmelerdeki Ejder Tasvirleri; Maşrapa, Sürahi/İbrik ve Şifa Taslarındaki Ejder Tasvirleri olarak üç ana başlık altında toplamam mümkündür. İlk gruptaki örnekleri daha çok duvar resimleri yani freskolar ve minyatürler oluşturmaktadır.

Mimariye bağlı elemanlarla ilişkilendirebileceğimiz ikinci grupta ise alt başlıklar altında çok fazla örnekle karşılaşılmamaktadır. Havuzla ilgili su ve ejder birlikteliği gerek minyatürlerden gerekse Evliya Çelebi'den edindiğimiz bilgilere göre oldukça değerli bir yere sahiptir. Mimari anlamda bu gruba dahil çörten, lüle vb. diğer örnekler ise oldukça sınırlı sayıdadır bununla birlikte ejderlerin tasvirlerinin değişmediği ve kullanım tarihlerinin geç Osmanlı Dönemi'ne kadar sürmesi ejderin su ile ilişkisinin Türk sanatındaki önemini bir kez daha vurgulamaktadır.

Türk İslam sanatında ejder su ilişkisinin işlendiği en büyük grubu maşrapalar ve ibrikler oluşturmaktadır. Maden başta olmak üzere porselen vd. malzemelerden yapılmış, Türk İslam Dönemi sürahi ve maşrapalarının bazılarında, kulp ya da emzik kısımlarında ejder gövdelerini ve/veya başlarını görmek mümkündür. İkonografik açıdan ele aldığımızda Uygur Dönemi’nden itibaren özelliklerini çok fazla ya da hiç değişmeden korudukları dikkat çekmektedir: Başında badem gözleri, kulakları, bazen topuz benzeri çıkıntısı, kanatları, balık pullu gövdesi ile yüzyıllar boyu Türk İslam sanatlarında varlık göstermişlerdir. Bu hâli ile Asya Hunlarından itibaren karşımıza çıkan kanatlı gök ejderi tasvirini yansıtmaları da diğer önemli özelliklerinden biridir.

Ejderi, gök, yer ve su unsurları ile birlikte düşündüğümüzde bu gerçeküstü hayvanın Türk sanatında yüzyıllar boyu oldukça çok kullanıldığı bilinmektedir. Bu kadar çok kullanım alanına sahip ejderin, yaşam kaynağı olan su ile birlikteliğinin tasvir edilmesi sembolik anlamda tesadüf değildir. Ejderin sembolik anlamı İslam öncesi dönemde çoğunlukla olumlu yöne işaret etmektedir. İslamiyet ile birlikte bu anlam neredeyse ikiye bölünür; ejder bazen kahramanların düşmanı bazen de şifa dağıtan bir figür hâline gelir. Bahsettiğimiz bu detay önemlidir çünkü ejder tasviri eğer su ya da suya ait unsur ile birlikte tasvir edildiğinde baharı, doğanın canlanmasını, bereketi, şifay1, iyiliği ve sonsuzluğu temsil eder. Özellikle çörten, çeşme, maşrapa, ibrik, şifa tası vb. eserlerde şifa getirmelerinin yanı sıra ölümsüzlük suyu ile de ilişkilendirilmektedirler. Sonuç olarak kısaca diyebiliriz ki Türklerin inancı ve sanatında ejder ile su birlikteliği her zaman "olumlu"yu gösteren taraf olmuştur.

\section{KAYNAKÇA}

Acun, H. (1997). Eyüp'ten Ejderli Bir Taş Suluk. I. Eyüpsultan Sempozyumu: Tebliğler. İstanbul: Seçil Ofset: 198-201.

Akçıl Harmankaya, N. Ç. (2018). Edirne Meriç/Mecidiye Köprüsü ve Üzerindeki Figürlü Taş Süslemeler. Art Sanat. 10: 148-167.

Allan, J. W. (1982). Islamic Metalwork The Nuhad Es-Said Collection, London: Sotheby. 
Altın, A. (2019). 12-14. Yüzyıl Türk-İslam Mimarisi ile Gotik Mimarisindeki Figürlü Yağmur Olukları Üzerine Bir Karşılaştırma Denemesi. Art Sanat. 12: 19-56.

And, M. (1998). Minyatürlerde Osmanlı-İslam Mitologyası. İstanbul : Akbank Kültür ve Sanat Müdürlüğü.

Atalay, B. (1992). Divanü Lûgati’t Türk Tercümesi. I. cilt. Ankara: TDK Yayıları.

Boydak, F. Ş. (2017). Bulut Motifinin Köken İtibariyle Ejderle Bağlantısı Üzerine. VIII. Uluslararası Türk Sanatı, Tarihi ve Folkloru Kongresi/Sanat Etkinlikleri: ss. 283-288.

Bozkurt, N. (1998). Hayvan. C Maddesi. TDV İslam Ansiklopedisi. C.17: 99-101.

Çaycı, A. (2002). Anadolu Selçuklu Sanatında Gezegen ve Burç Tasvirleri. Ankara : Kültür Bakanlığı.

Çevrimli, N. (2012). Değişik İşlevli Bir Grup Madeni Eser Üzerinde Görülen Ejder Figürleri Hakkında Bir Değerlendirme. Vakıflar Dergisi. Haziran, Sayı 37: 193-222.

Çınar, S. (2014). Erzurum Arkeoloji Müzesi Deposunda Bulunan Kaçkar Dönemine ait Bir Grup İbrik. Art Sanat, 2: 163-183.

Çoruhlu, Y. (2011). Bezeklik XIX.Tapınak'ta Bulunan Ejderha Figürlü Uygur Duvar Resmi. Özsait Armağını. Mehmet ve Nesrin Özsait Onuruna Sunulan Makaleler: ss. 127-141. Antalya: Sunan-İnan Kıraç Akdeniz Medeniyetleri Araştırma Enstitüsü Yayınları.

Çoruhlu, Y. (2015). Türk Mitolojisinin Anahatları. İstanbul: Kabalcı Yayınevi.

Çoruhlu, Y. (2019). Kozmolojik, Mitolojik, Astrolojik Dini ve Edebi Tasavvurlara Göre Türk Sanatında Hayvan Sembolizmi: Proto-Türk Devrinden, MS. 14. Yüzyıla Kadar Efsanevi ve Yırtıcı Hayvanların Sembolizmi ÜZzerine Bir Deneme. İstanbul: Ötüken Neşriyat.

Doğanay, A. (2017). Koca Sinan'ın Üç Büyük Eserinde Rahmet Olukları: Çörtenler. Mimar Sinan ve Su. Sultangazi Belediyesi Kültür ve Sosyal İşler Müdürlüğ̈̈ Yayınları: ss. 127-179. İstanbul: Kültür Sanat Basımevi.

El Cezerî (2002). El-Câmi' Beyne'l-İlm Ve'l-Amel En-Nâfi' Fi Es-Sinaâ'ti'ül-Hiyel. (çeviri, inceleme, teknik açıklamalar, Sevim Tekeli, Yavuz Kanat, Melek Dosay). Ankara: Türk Tarih Kurumu Basimevi.

Esin, E. 2001. Türk Kozmolojisine Giriş. İstanbul: Kabalc1 Yayınevi.

Esin, E. 1979. Türk Kozmolojisi (İlk Devir Üzerine Araştırmalar). İstanbul: İstanbul Üniversitesi Edebiyat Fakültesi Matbaası.

Esin, E. 1970. Evren (Selçuklu Sanatı Evren Tasvirinin Türk İkonografisinde Menşeleri). Selçuklu Araştırmaları Dergisi, 1: 161-182.

Esin, E. 1982. Bezeklik Külliyesi'nde Dokuzuncu Tapınak. Türkiyemiz, 37: 1-6.

Gedük, S. (2017). Suyun İyileştirici Gücü Şifa Kapları. Z Dergisi, 2: 358-361. 
Gök, M. (edt.) (2010). Ab-ı Hayat: Geçmişten Günümüze İstanbul'da Su ve Su Kültürü. İstanbul : Adell Armatür Vana.

Hartel, H. vd. (1982). Along the Ancient Silk Routes: Central Asian Art From the West Berlin State Museums. New York: The Metropolitan Museum of Art.

Karamağaralı, B. (1976). Anadolu'da XII-XVI. Asırlardaki Tarîkat ve Tekke Sanatı Hakkında. Ankara Üniversitesi Illahiyat Fakültesi Dergisi, C.XXI: 247-284.

Korkutata, Y. (2012). El-Cezeri'nin Hayatı ve Terazili Sürekli Çalan Flüt Adlı Çalışması. Dicle Üniversitesi Fen Bilimleri Enstitüsü, İnşaat Mühendisliği Anabilim Dalı, Basılmamış Yüksek Lisans Tezi, Diyarbakır.

Le Coq, A. von. (1924). Die Buddhistische Spätantike in Mittelasien. Vol.3-vol.4, Berlin.

Lentz, T. ve Glenn Lowry. (1989). Timur and the Princely Vision: Persian Art and Culture of the Fifteenth Century, Los Angeles.

Malekzadeh, F. (1976-1977). Topkapı Sarayı Müzesinde Bulunan Şah İsmail-i Safevi’ye ait Kupa. $\quad$ Tarih Enstitüsü Dergisi, Say1 7-8: 263-276.

Önge, Y. (1970). Anadolu'da Ejder Başlı Madenî Çeşme Lüleleri. Selçuklu Araştırmaları Dergisi. I, $\quad$ 1969. Ankara: Türk Tarih Kurumu Basımevi: 183-185.

Özüdoğru, Ş. (1989). Karaman'da Türk Mimari Eserleri Süslemeleri. Basılmamış Doktora Tezi. Mimar Sinan Güzel Sanatlar Üniversitesi, Sosyal Bilimler Enstitüsü. İstanbul.

Pakyüz, A. (2015). Osmanl Minyatüründe Melek İmgesi (16. yüzyll Sonuna Kadar Melek Figürüne İkonografik Bir Bakış Denemesi). Basılmamış Yüksek Lisans Tezi. Marmara Üniversitesi/ Türkiyat Araştırmaları Enstitüsü Türk Sanatı Anabilim Dalı. İstanbul.

Polosmak, N. vd. (2011). Dvatsatty Noin-Ulinskiy Kurgan. Infolio: Novosibirsk.

Pinder-Wilson, R. H. (1962). A Persian Jade Cup.The British Museum Quarterly, Vol. 26, No. $1 / 2 \quad$ (Sep.): $49-50$.

Şahin, S. ve Ş. Sönmezer. (2017). Osmanlı Mimarisinde Figürlü Tasvir Sanatı Hakkında Daha Önce Bilinmeyen Bir Örnek: 1. Mahmut Su Kemeri. Sanat Tarihi Yıllığı, XXVI, Say1 26. 105-140.

Şimşek, F. (2019). Klasik Osmanlı Minyatüründe Havuz İmgesi. Basılmamış Yüksek Lisans Tezi. Marmara Üniversitesi/Türkiyat Araştırmaları Enstitüsü, Türk Sanatı Anabilim Dalı, İstanbul.

von Folsach, K. (2001). Art of the World in the David Collection. Copenhagen.

https://gulbekian.pt. Erişim Tarihi: 18.02.2020. 


\section{Görsel Listesi}

Görsel 1a. Noin-Ula Kurganı'nda bulunan at koşumuna ait ejder figürleri, Polosmak-vd., 2011, res.6.

Görsel 1b. Sudan Çıkan Gök Ejderi, Fresko, Bezeklik 19. Tapınak, 9-10.yüzyıl, Çoruhlu, 2019, resim 105.

Görsel 1c. Ejder biçiminde temsil edilen Tenniyn Yıldızı, Acaibü'l Mahlukat, BL Add 7894. And, s.326.

Görsel 1d. Bulutlar arasında ejder, Acaibü'l Mahlukat TSM. Env. A3632, vr.123b, 13-14.yüzyıl. Çaycı, r. 36.

Görsel 2. Duvar resmi, Ejder Sandalı Üzerinde Budha, Kızıl/Müzisyenler Mağaras1, 600-650 yılları arası. Hartel vd., 1982:85.

Görsel 3. "Hz Yûnus'un, Cebrâil'in yardımıyla balığın karnından çıkması", Ravzatü's-Safâ, SK Damat İbrahim Paşa. And: 218.

Görsel 4. Ejderha'nın Nil'de Yıkanacak olan Yûsuf'u bakışlara karşı örtmesi, Yûsuf-u Zileyhâ, And: 409.

Görsel 5a. Bir Çift Gök Ejderi, Bezeklik 9. Tapınak, 9-14.yüzyıl, Çoruhlu, 2019, çiz.17.

Görsel 5b. Koço A Tapınăğ'ndan fresko parçası üzerinde havuzda ejder tasviri, Çoruhlu, 2011, r. 5.

Görsel 6a. "Osman Paşa, Sultan III. Murad'ın Huzurunda" isimli minyatür ve bu minyatürden havuz detayı. Şecaatnâme, İÜK. T. 6043, y.7b. Şimşek, fot.4.67; çiz.4.34.

Görsel 6b. Tombak fiskiye detayı, 16.yy. Ülkü, 1995, kat. No.47.

Görsel 7. Orhan Gazi'nin Kaluyaven Bey'e kendi çektiği bir oku hediye etmesi. Hünernâme, I. cilt, TSMK. H. 1523, y.72. Şimşek, Fot. 4.33 .

Görsel 8a. Karaman Arapzade (Arapoğlu ) Camii, Altın, G.19.

Görsel 8b. Abdullah Mustafa Türbesi, Doğanay, resim 12.

Görsel 9a. I. Mahmud Su Kemeri kilit taş1;Ejder/yılan baş1. Şahin ve Sönmezer, f.5.

Görsel 9b. Edirne Meriç/Mecidiye Köprüsü'nden detay. Akçıl Harmankaya, 2018, G.4.

Görsel 10. Eyüp'ten taş suluk. Acun, fotoğraf 3-4.

Görsel 11a. Hatun Han çeşmesine ait lüle, Önge, resim 5.

Görsel 11b. Karakaya Kaplıcası çeşmesine ait lüle, Önge, resim 4.

Görsel 11c. Çeşme lülesi, Osmanlı Dönemi, (18.yüzyıl), Adell Armatür Koleksiyonu,

Görsel 12a. Caloueste Gulbekian Müzesi'nden beyaz yeşim taşından ejder kulplu maşrapa.http://gulbekian.pt

Görsel 12b. Yeşim Taşı kap, Lentz - Lovry, cat. 124.

Görsel 12c. Yeşim taşı kap, Lentz - Lowry, cat. 52.

Görsel 12e. Şah İsmail Safavi için dekore edilen yeşim taşından maşrapa, Lentz - Lowry, fig. 102.

Görsel 13a. Londra Victoria ve Albert Müzesi, maşrapa, Kaya, resim 7a.

Görsel 13b. Nuhad es-Said Koleksiyonu'ndan maşrapa, Allan:111.

Görsel 13c. TİEM'den maşrapa. Çevrimli, resim 19.

Görsel 13d. Afganistan Herat’tan ejder kulplu maşrapa, Von Folsach, Fot. 523.

Görsel 13e. Osmanlı Dönemi ejder kulplu maşrapa, Von Folsach, Fot. 531.

Görsel 14a. Erzurum Arkeoloji Müzesi'nden envanter 9:89 no.lu ibrik, Çınar, fot.6.

Görsel 14b. 18.yy bronz ibrik, Gök, fot.35.

Görsel 14c. 19.yy Osmanlı Dönemi pirinç ibrik, Gök: 149.

Görsel 15a. Abdest Almak İçin Düzenlenmiş Otomat, Korkutata, şekil 11.

Görsel 15b. Abdest Almak İçin Su Döken Çocuk, Korkutata, şekil 12.

Görsel 15c. Köleli Leğen, El-Cezeri, Şekil 2.119.

Görsel 15d. Kayık Su Saati, Yusuf Korkutata, şekil 15.

Görsel 15e. Filli Su Saati, Yusuf Korkutata, şekil 16.

Görsel 16. Selçuklu Dönemi şifa tas1, Gedük: 359.

Görsel 17a. Dünya ağacının dalları ejder arasında ejder başları, 8. yüzyıl, Esin, 1970, res. 4.

Görsel 17b. 13. yüzyıla sonuna ait N. Sivasî'nin Malik Abû Ahnaf’n tasviri, Esin, 1970, res. 16. 


\section{GÖRSELLER}
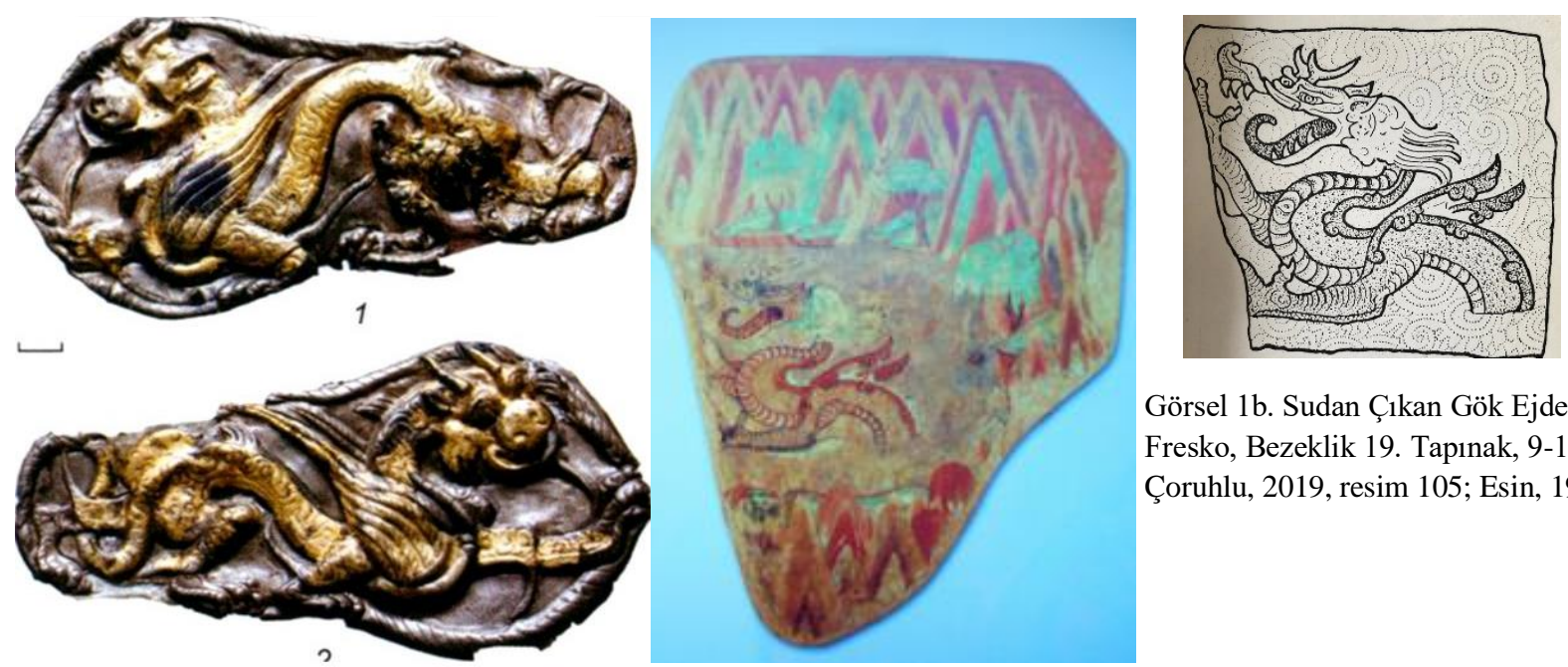

Görsel 1b. Sudan Çıkan Gök Ejderi ve detayı Fresko, Bezeklik 19. Tapınak, 9-10.yüzyıl, Çoruhlu, 2019, resim 105; Esin, 1970, res.17.

Görsel 1a. 20 no.lu Noin-Ula Kurganı'nda bulunan at koşumuna ait ejder figürleri, Polosmak-vd., 2011, res. 6).

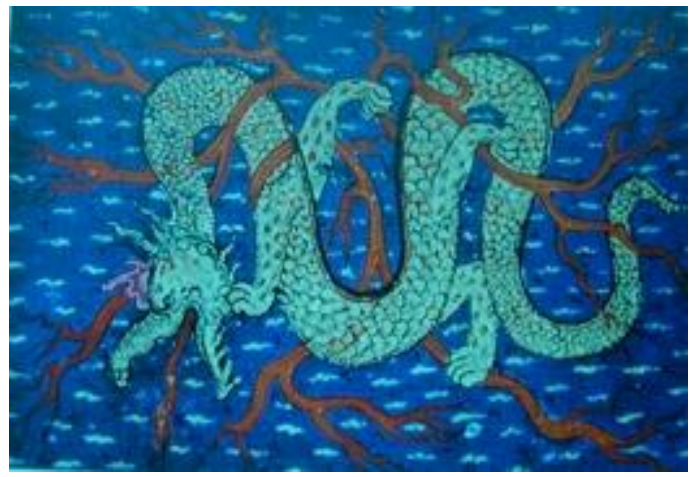

Görsel 1c. Ejder biçiminde temsil edilen Tenniyn Yıldızı, Acaibü'l Mahlukat, BL Add 7894. And, s.326

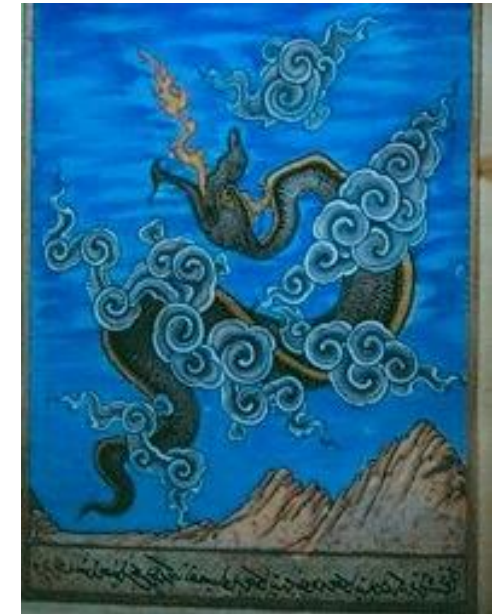

Görsel 1d. Bulutlar arasında ejder, Acaibü'l Mahlukat, TSM. Env. A3632, vr.123b, 13-14.yüzyı1. Çayc1, r. 36. 


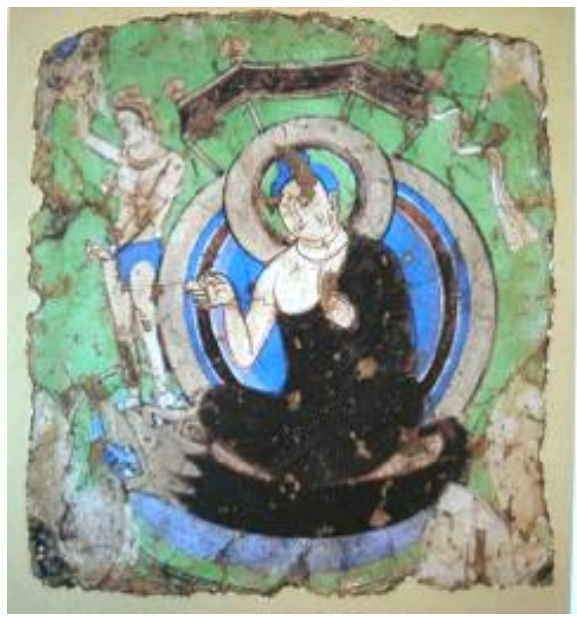

Görsel 2. Duvar resmi, Ejder Sandalı Üzerinde Budha, Kızı1/Müzisyenler Mağarası, 600-650 yılları arası. Hartel vd., 1982:85

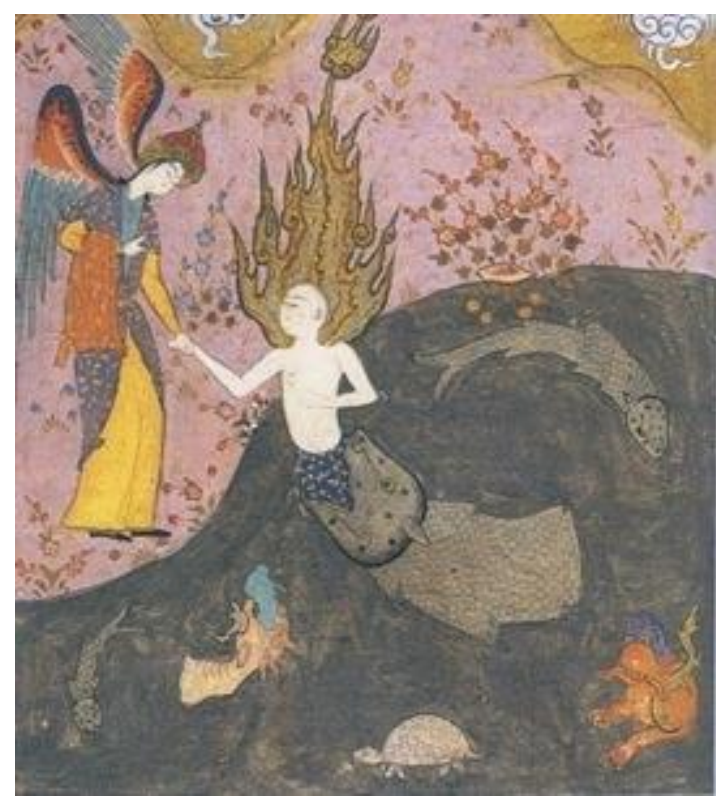

Görsel 3. "Hz Yûnus'un, Cebrâil'in yardımıyla balığın karnından çıkması",

Ravzatü's-Safâ, SK Damat İbrahim Paşa. And: 218.

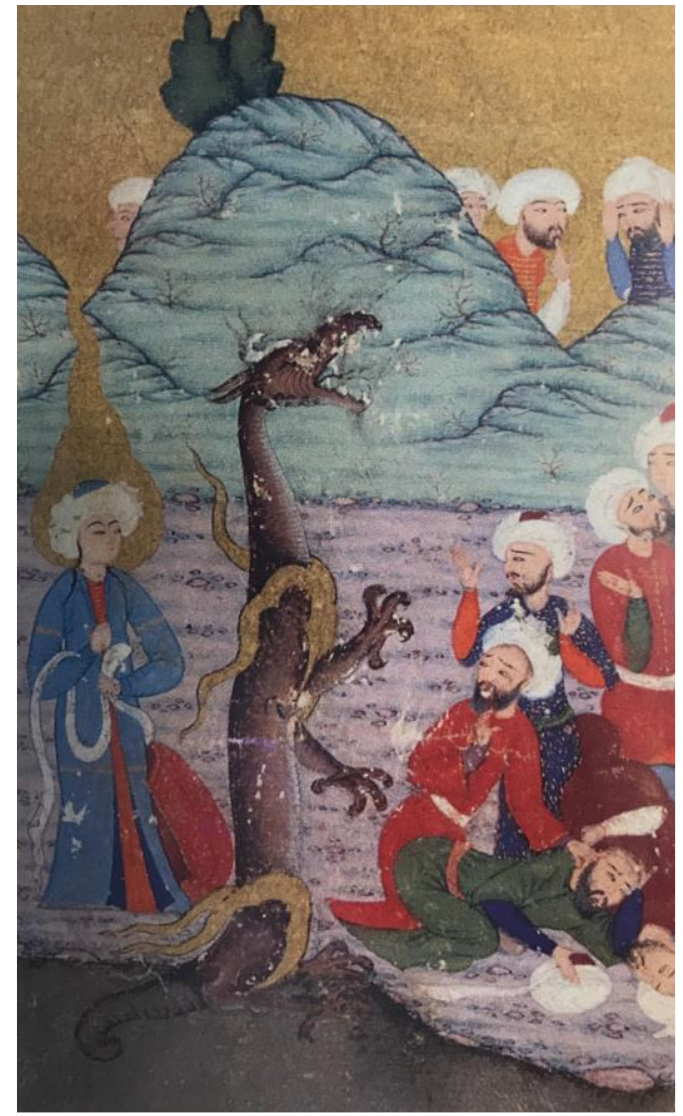

Görsel 4. Ejderha'nın Nil'de Yıkanacak olan Yûsuf'u bakışlara karşı örtmesi, Yûsuf-u Züleyhâ, And: 409. 


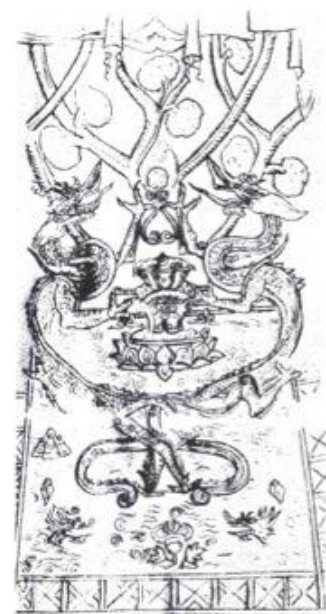

Görsel 5a. Bir Çift Gök Ejderi, Bezeklik 9. Tapınak, 9-14.yüzyıl, Esin, 1970, res. 2.

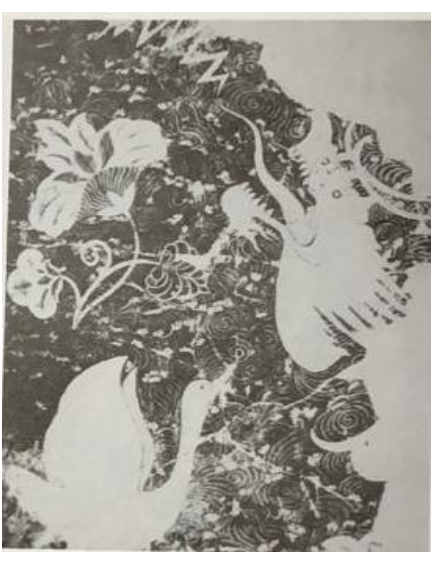

Görsel 5b. Koço A Tapınağı'ndan fresko parçası üzerinde havuzda ejder tasviri, Çoruhlu, 2011, r. 5.
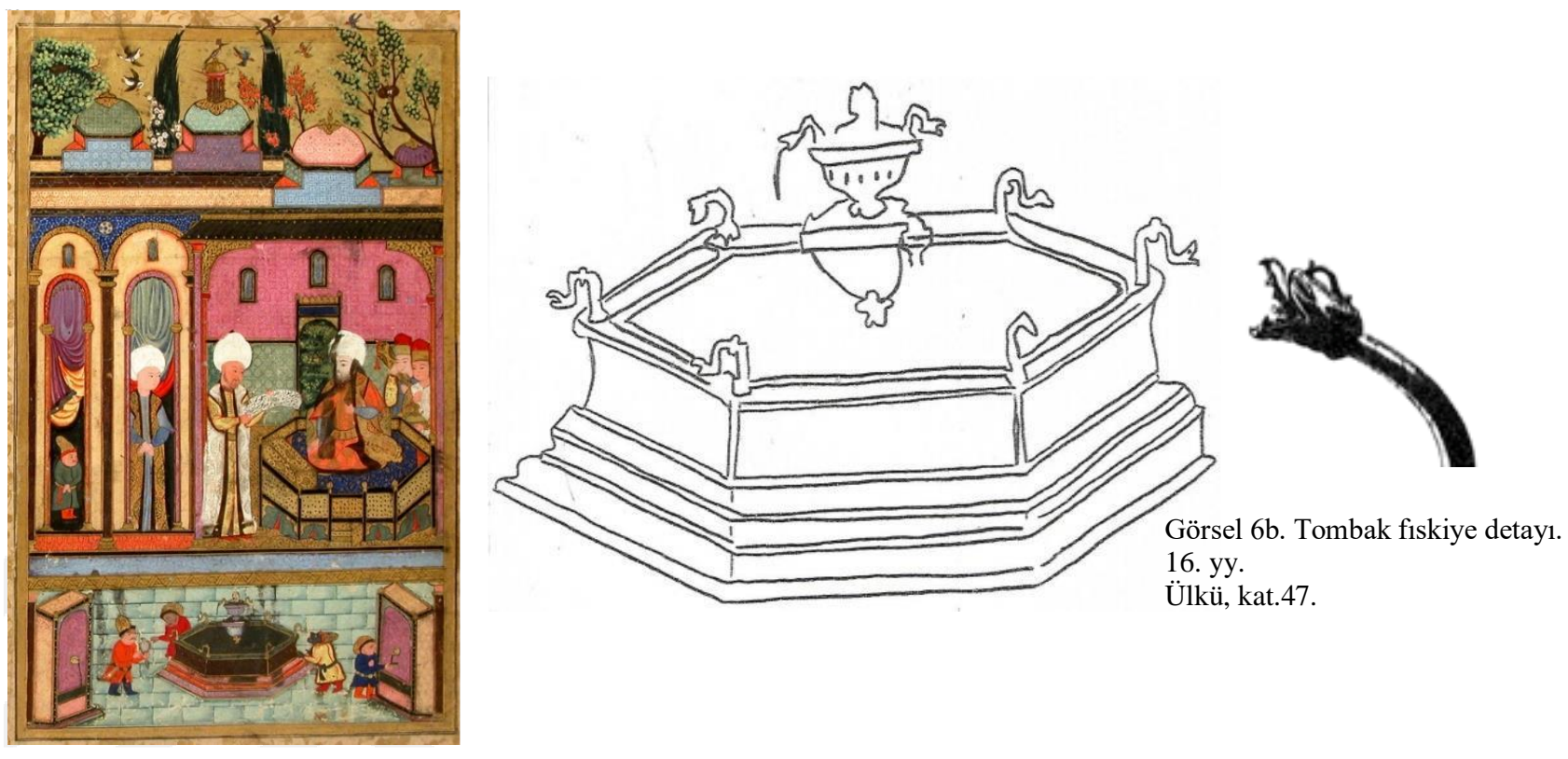

Görsel 6a. "Osman Paşa, Sultan III. Murad'ın Huzurunda" isimli minyatür ve bu minyatürden havuz detayı. Şecaatnâme, İÜK. T. 6043, y.7b.

Şimșek, fot.4.67; çiz.4.34. 


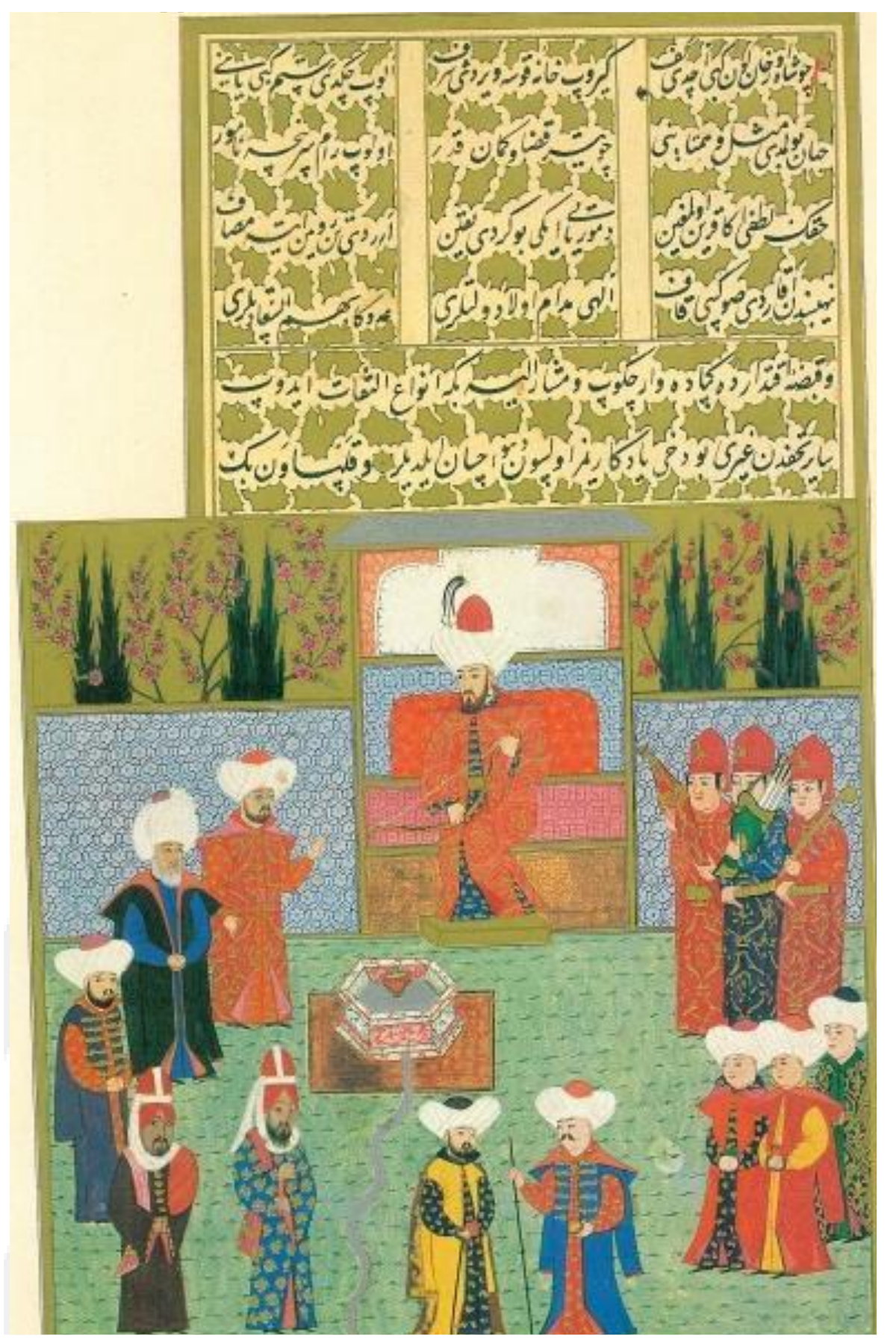

Görsel 7. Orhan Gazi’nin Kaluyaven Bey’e kendi çektiği bir oku hediye etmesi. Hünernâme, I. cilt, TSMK. H. 1523, y.72. Şimşek, Fot. 4.33. 


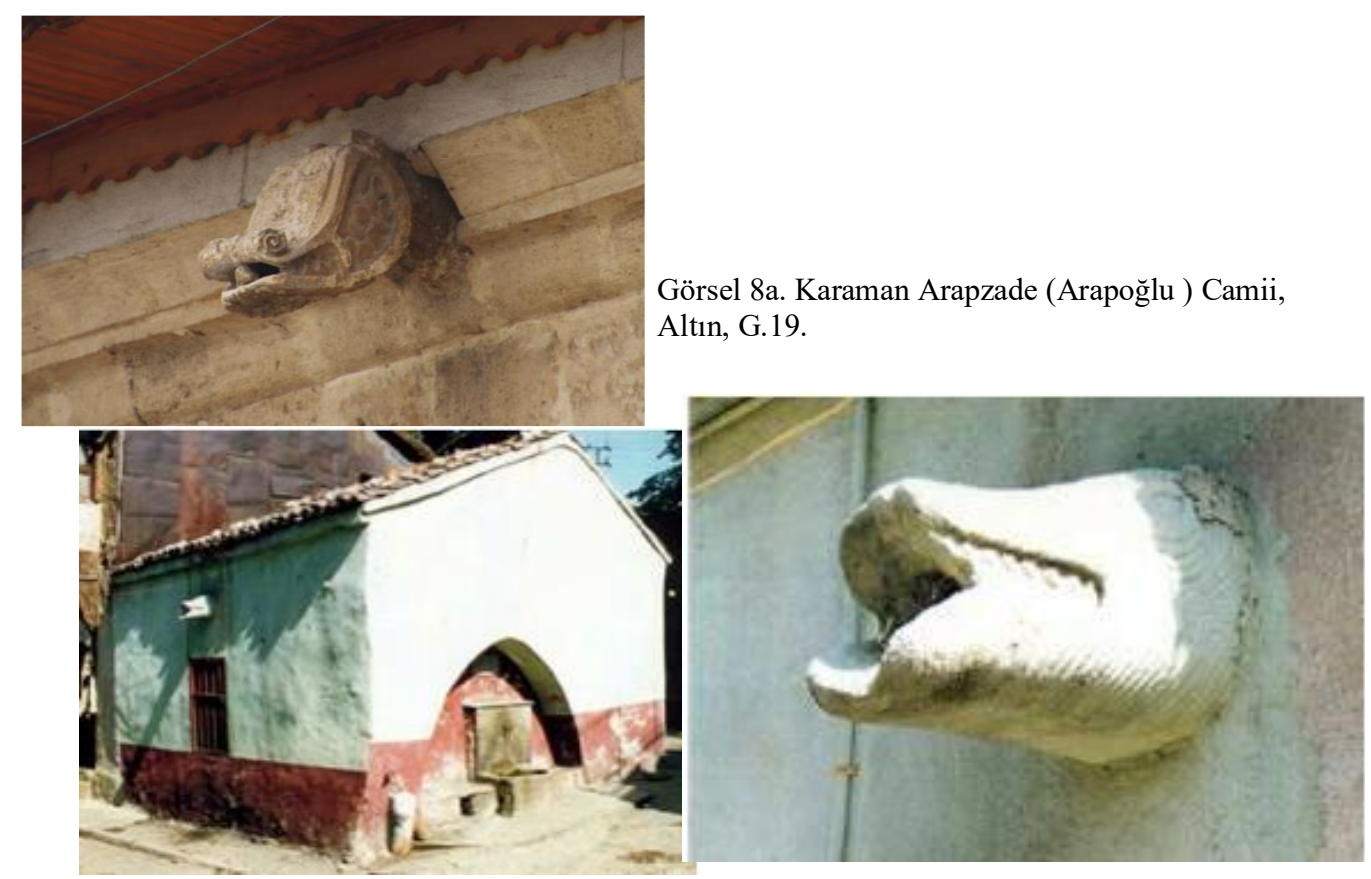

Görsel 8b. Abdullah Mustafa Türbesi

Doğanay, resim 12.

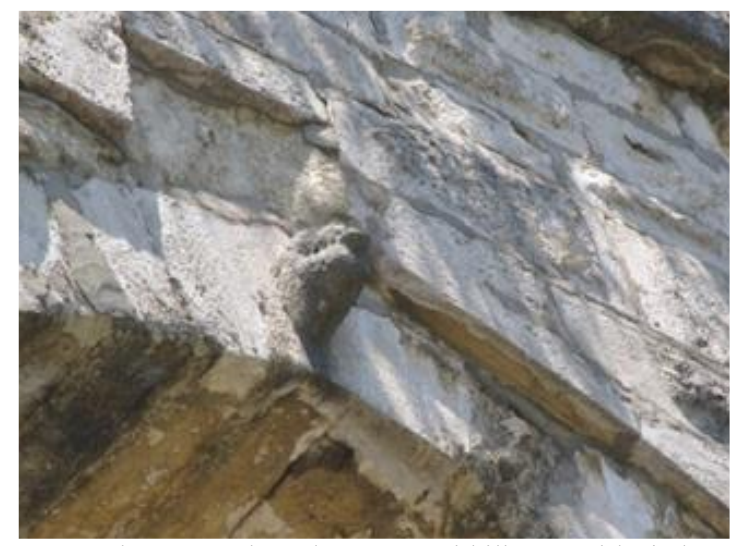

Görsel 9a. I. Mahmud Su Kemeri kilit taşı:Ejder/yılan baş1.

Şahin ve Sönmezer, f.5.

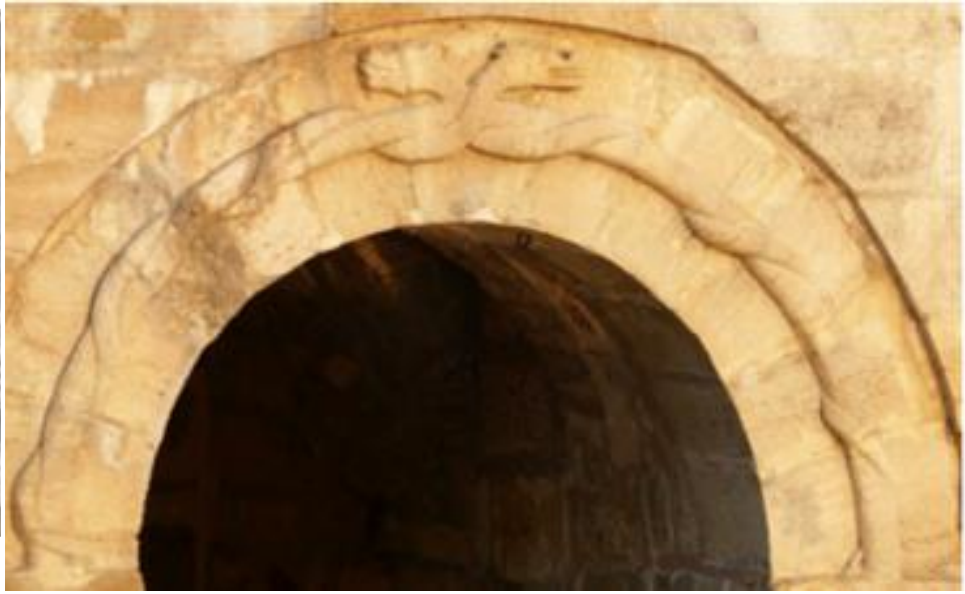

Görsel 9b. Edirne Meriç/Mecidiye Köprüsü'nden detay Akçıl Harmankaya, G.4.

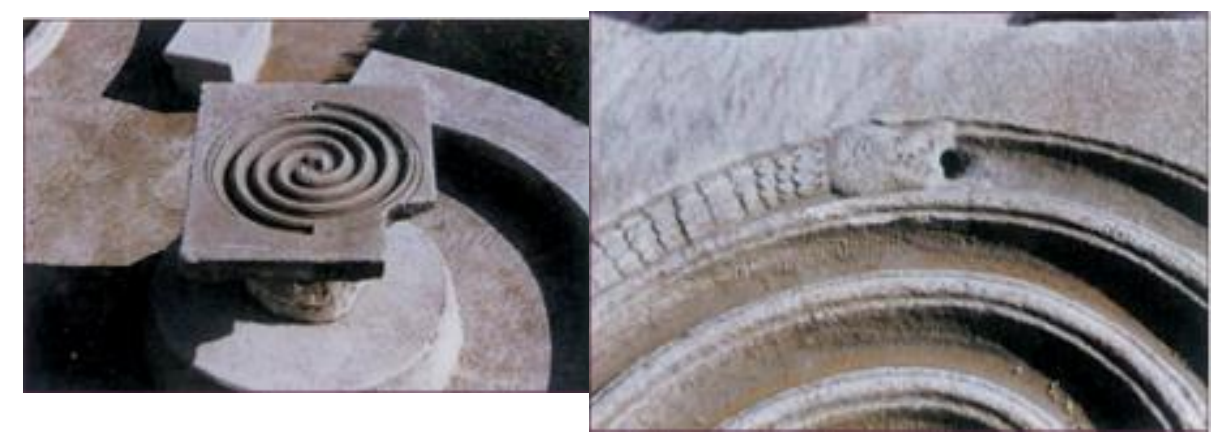

Görsel 10. Eyüp'ten taş suluk.

Acun, fot. 3-4. 


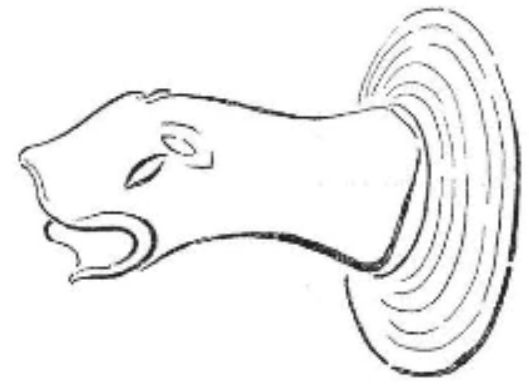

Görsel 11a. Hatun Han çeșmesine ait

lüle,

Önge, resim 5.

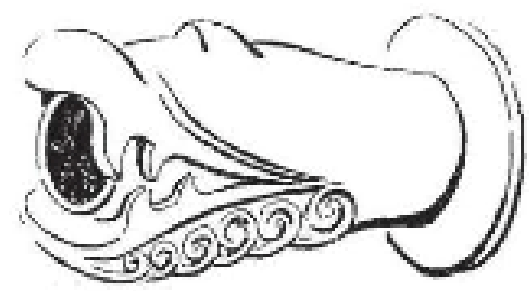

Görsel 11b. Karakaya Kaplıcası çeşmesine ait lüle,

Önge, resim 4.

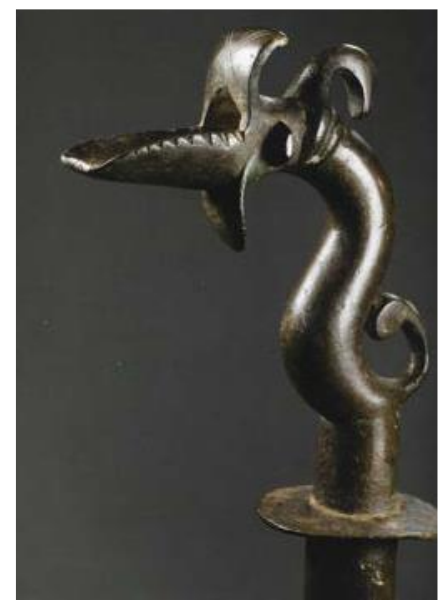

Görsel 11c. Çeşme lülesi, Osmanlı Dönemi, (18.yüzyıl), Adell Armatür Koleksiyonu, 


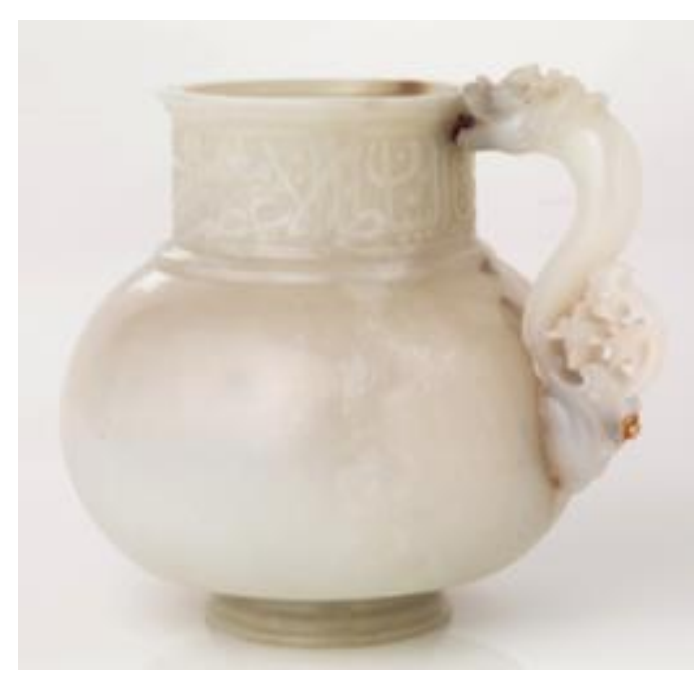

Görsel 12a. Caloueste Gulbekian Müzesi'nden beyaz yeşim taşından ejder kulplu maşrapa.

http://gulbekian.pt

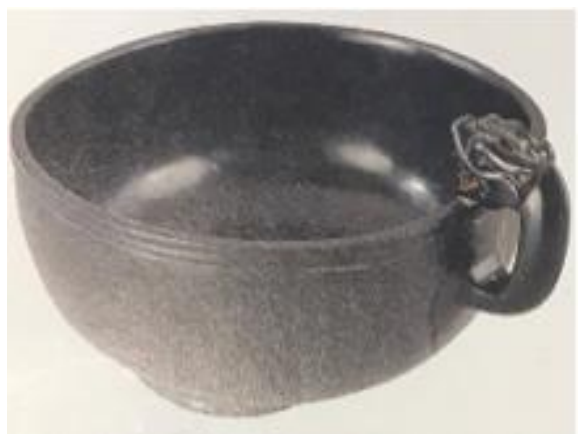

Görsel 12c. Yeşim taşı kap

Lentz - Lowry, cat. 52.

Görsel 12e. Șah İsmail Safavi için dekore edilen yeșim taşından maşrapa. Lentz - Lowry, fig.102.

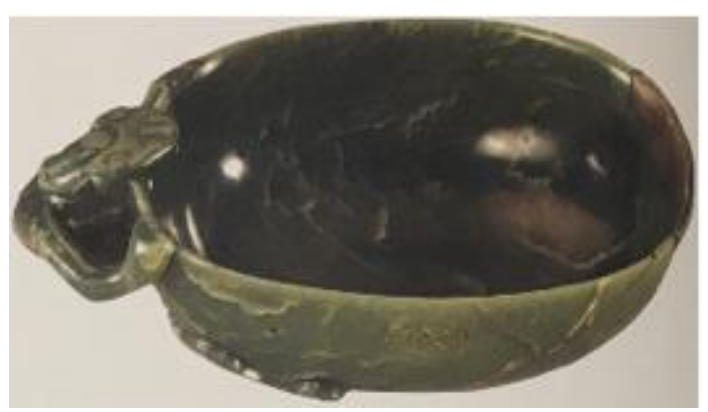

Görsel 12b. Yeșim Taşı kap,

Lentz - Lovry, cat. 124.

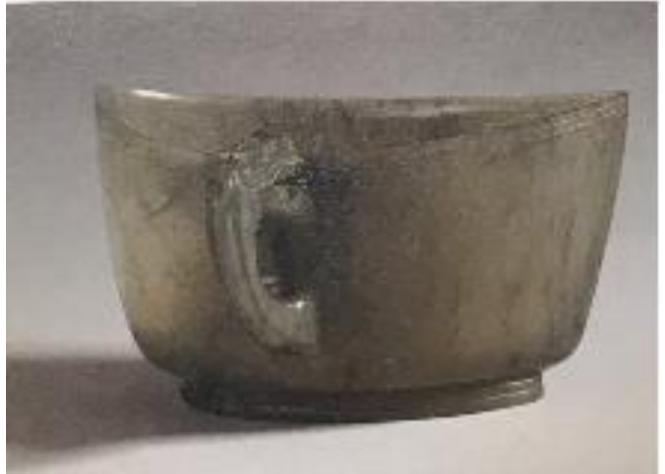

Görsel 12d. Oval formlu yeşim taşından kap, Lentz - Lowry, cat.no.120.

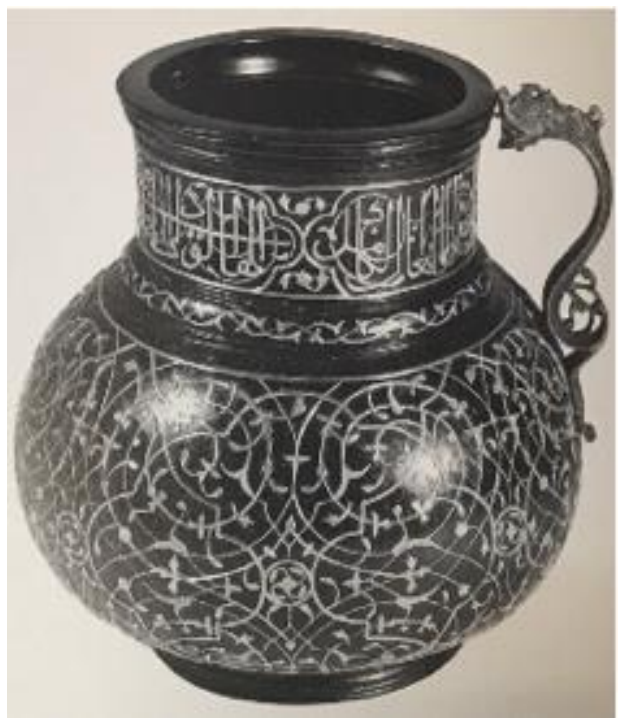




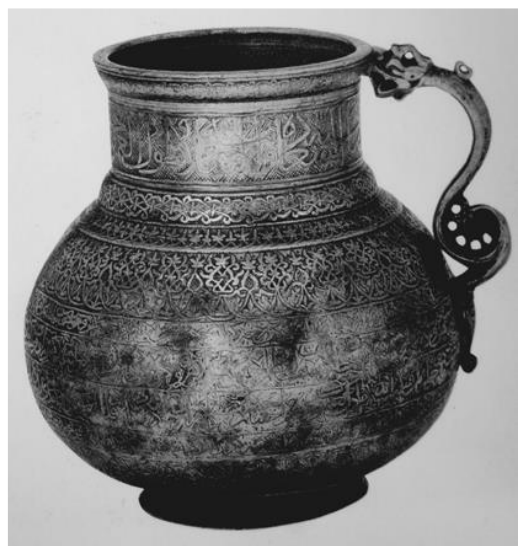

Görsel 13a. Londra Victoria ve Albert Müzesi, maşrapa, Kaya, resim 7a.

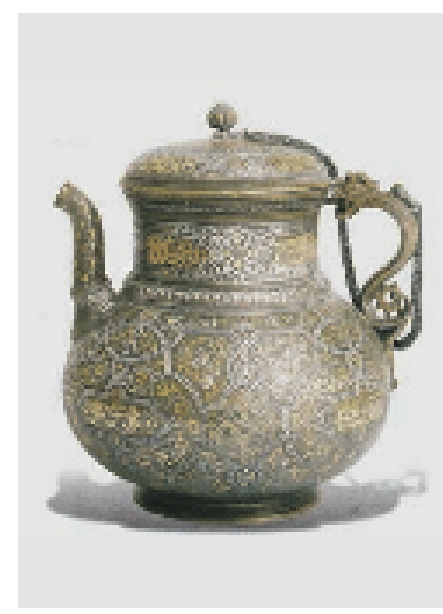

Görsel 13c. TİEM'den maşrapa. Çevrimli, resim 19.

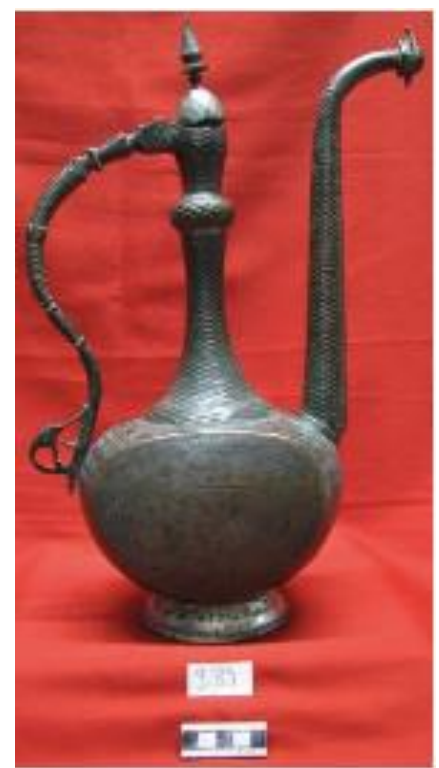

Görsel 14a. Erzurum Arkeoloji Müzesi'nden envanter 9:89 no.lu ibrik, Çınar, fot. 6 .

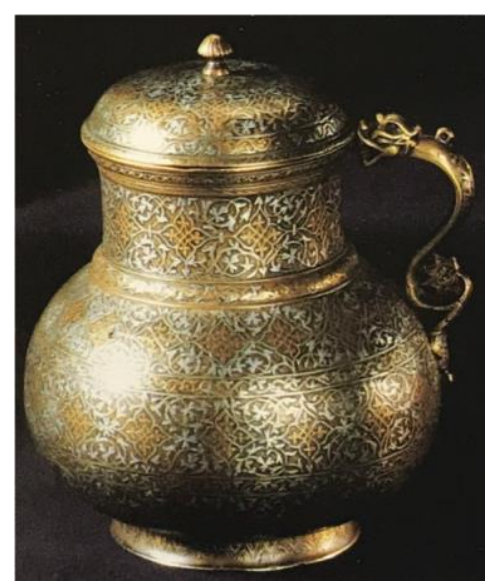

Görsel 13d. Afganistan Herat'tan ejder kulplu maşrapa,

Von Folsach, Fot. 523.

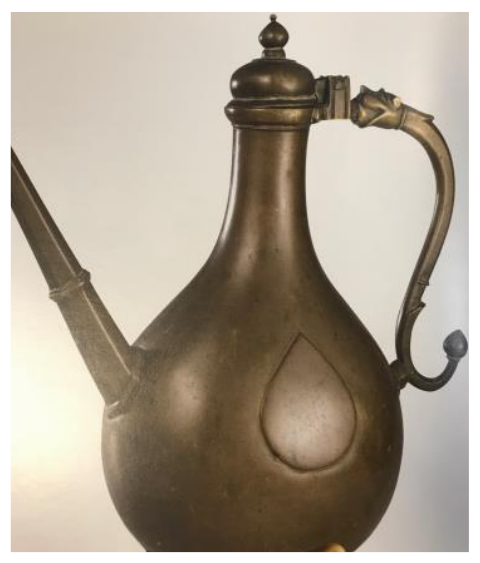

Görsel 14b. 18.yy bronz ibrik, Gök, fot.35.

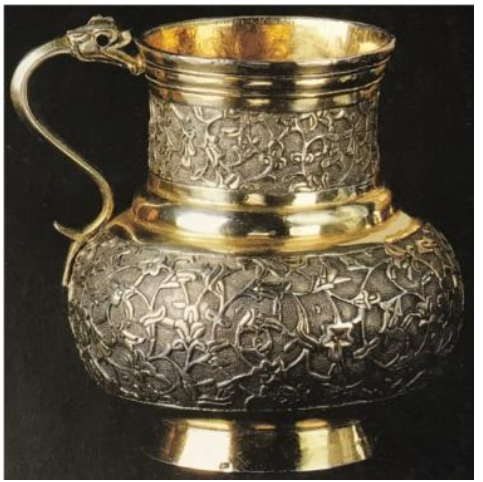

Görsel 13e. Osmanlı Dönemi ejder kulplu maşrapa, Von Folsach, Fot. 531.

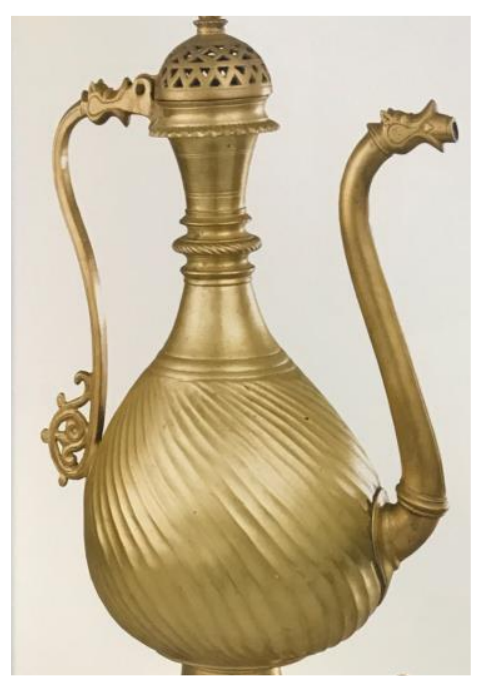

Görsel 14c. 19.yy Osmanlı Dönemi pirinç ibrik, Gök, s.149. 


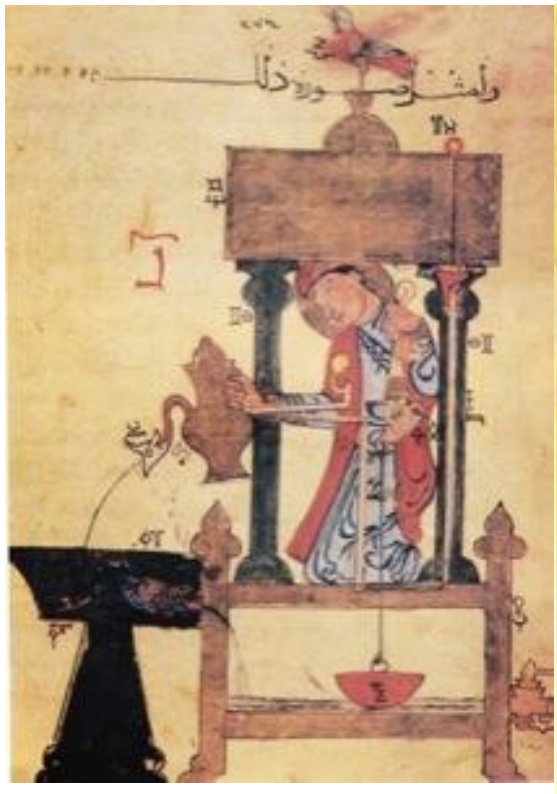

Görsel 15a. Abdest Almak İçin Düzenlenmiş Otomat,

Korkutata, şekil 11.

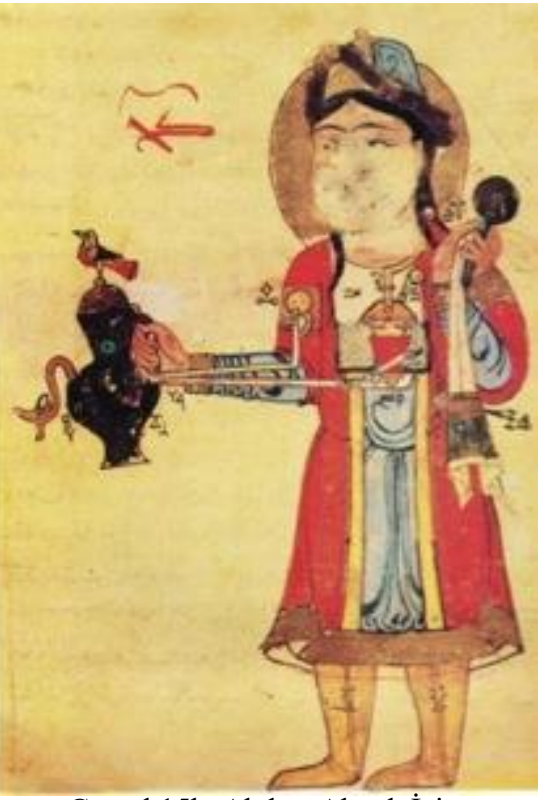

Görsel 15b. Abdest Almak İçin Su Döken Çocuk,

Korkutata, şekil 12.

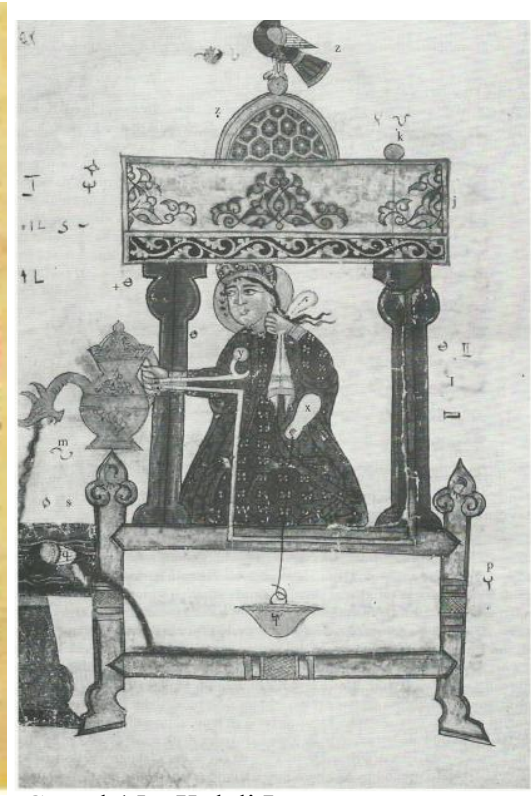

Görsel 15c. Köleli Leğen, El-Cezeri, Şekil 2.119.
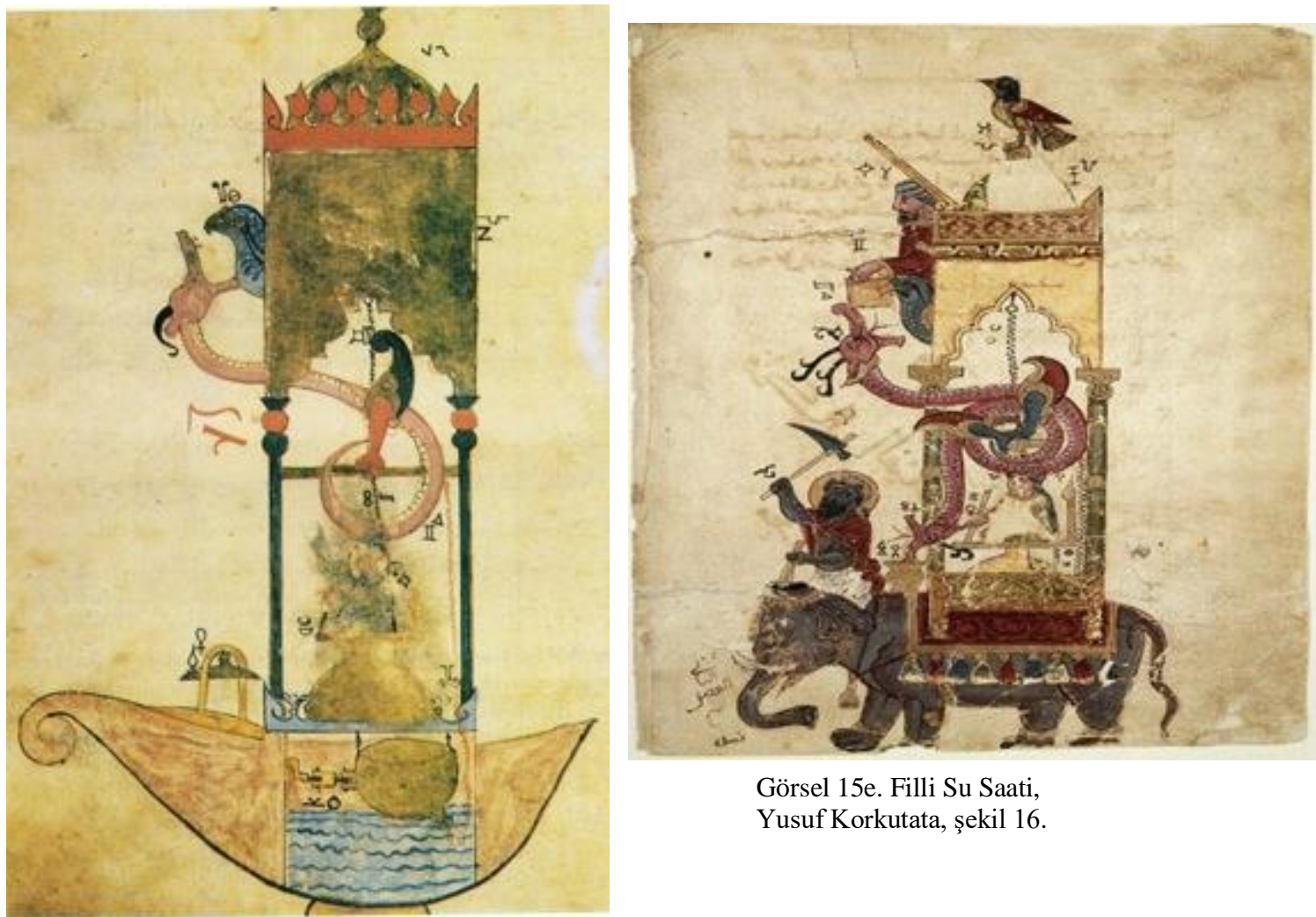

Görsel 15e. Filli Su Saati,

Yusuf Korkutata, şekil 16.

Görsel 15d. Kayık Su Saati,

Yusuf Korkutata, şekil 15. 


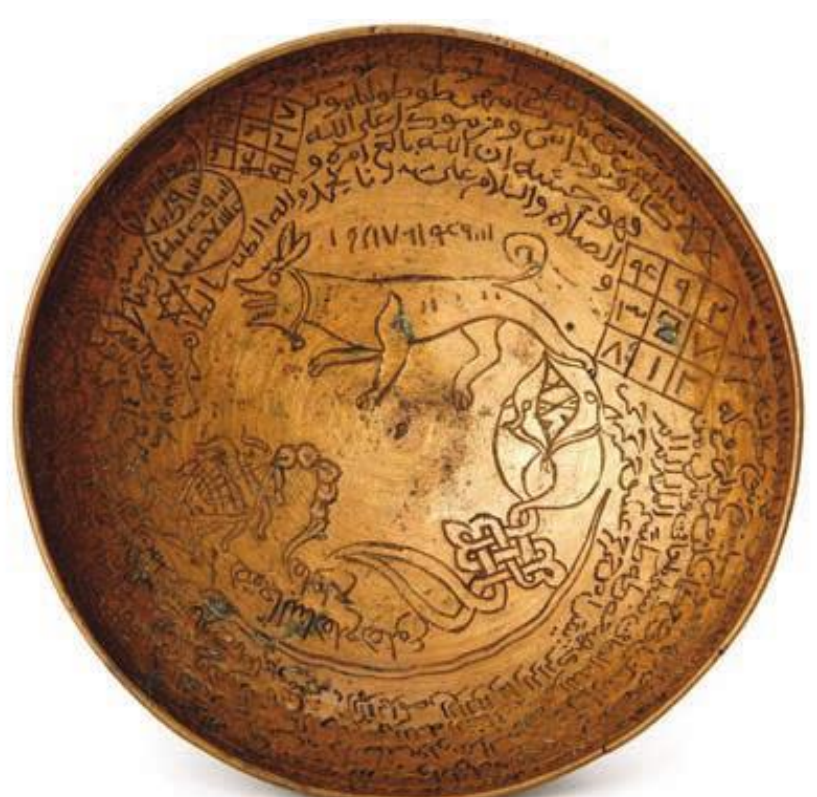

Görsel 16. Selçuklu Dönemi şifa tası, Gedük: 359.

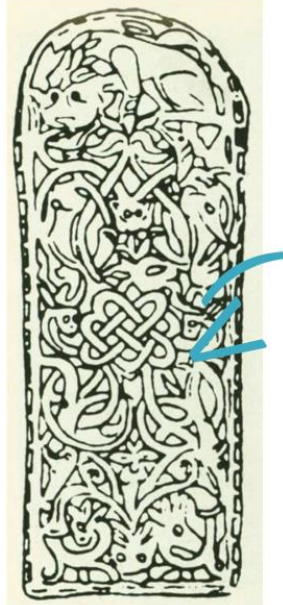

Görsel 17a. Dünya ağacının dalları ejder arasında ejder başları, 8. yüzyıl, Esin, 1970, res. 4.

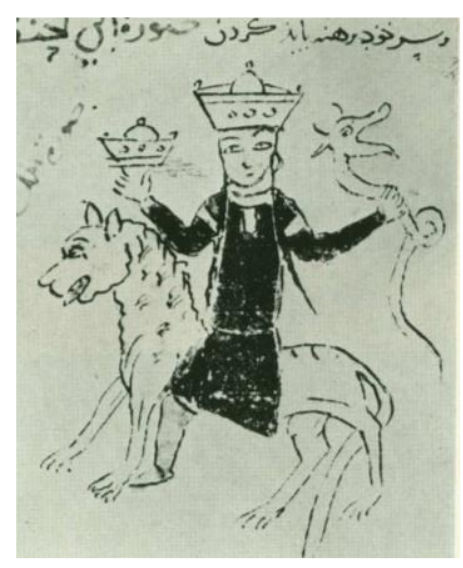

Görsel 17b. 13. yüzyıla sonuna ait N. Sivasî'nin Malik Abû Ahnaf'ın tasviri, Esin, 1970, res. 16. 